Chemical Analyses and Physical Properties of 12 Coal Samples from the Pocahontas Field, Tazewell County, Virginia, and McDowell County, West Virginia

G E O L O G I C A L S U R V E Y B U L L E T I N 1528 



\section{Chemical Analyses and Physical Properties of 12 Coal Samples from the Pocahontas Field, Tazewell County, Virginia, and McDowell County, West Virginia}

By VIRGIL A. TRENT, JACK H. MEDLIN, S. LYNN GOLEMAN, and RONALD W. STANTON

G E O L O G I C A L S U R V E Y B U L L E T I N 1528

$A$ discussion of the metamorphic rank, major and minor element content, and physical properties of 12 coal samples from the Pocahontas coal field

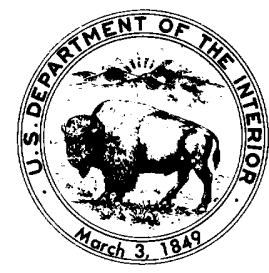


UNITED STATES DEPARTMENT OF THE INTERIOR

JAMES G. WATT, Secretary

GEOLOGICAL SURVEY

Dallas L. Peck, Director

\section{Library of Congress Cataloging in Publication Data}

Main entry under title:

Chemical analyses and physical properties of 12 coal samples from the Pocahontas field, Tazewell County, Virginia, and McDowell County, West Virginia.

(Geological Survey bulletin ; 1528)

Bibliography: $p$.

Supt. of Docs. no.: I 19.3:1528

1. Coal_Virginia-Tazewell County-Analysis. 2. Coal_West Virginia-McDowell CountyAnalysis. I. Trent, Virgil A. II. Series.

QE75.B9 vo. 1528 [TP326.U5] 557.3

81-607871

[662.6'224'09755763]

AACR2 
Abstract

Introduction

Geographic setting -

Scope of present study

Previous investigations

Acknowledgments _-__

Geological setting -

Stratigraphy _-_-_-_-_- 4

Structure

Metamorphism_-___-__- 6

Chemical composition

U.S. Department of Energy standard coal analysis

Sulfur content

Coal rank variations with depth

U.S. Geological Survey coal analyses

U.S. Geological Survey coal analyses of laboratory ash

U.S. Geological Survey coal analyses on a whole-coal basis _._-__-_- 14

Physical properties ...

U.S. Department of Energy standard coal analyses

Moisture, ash, and heat of combustion (heat value) _-_______- 15

Density (specific gravity)

Free-swelling index number -

Ash-fusion temperatures

Coal petrography _._- 24

Coal geology -

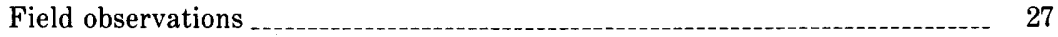

Pocahontas No. 4 coal bed

Color, texture, banding, and hardness

Cleat (jointing)

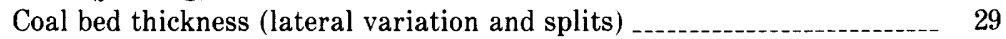

Roof- and floor-rock characteristics _._-_._- 30

Coal rank variations by bed

Pocahontas No. 3 coal bed

Pocahontas No. 4 coal bed_-_- 32

War Creek-Lower Horsepen coal zone _._-_-_-_._- 32

Upper Horsepen coal bed

Environments of coal deposition -

Conclusions _-

References cited -..--_-

\section{ILLUSTRATIONS}

[Plates in pocket]

Plate 1. Map showing coal sample localities in McDowell County, W. Va., and Tazewell County, Va.

2. Generalized column showing coal-bed stratigraphy.

3. Geologic map of the study area. 
FIgURE 1. Index map showing location of study area in West Virginia and

Virginia

2. Flowsheet of sample preparation and chemical analysis of coal

3. Linear regression curves and correlation coefficients for depth

(thickness) and fixed-carbon content of 12 bituminous coal samples $(A)$ and depth (thickness) and carbon-hydrogen atomic ratios of 12 bituminous coal samples $(B)$

\section{TABLES}

TABLE 1. Proximate and ultimate analyses, heat content, forms of sulfur, freeswelling index, ash-fusion temperature, and specific-gravity determinations for 12 coal samples from Virginia and West Virginia

2. Arithmetic mean, observed range, geometric mean, and geometric deviation of proximate and ultimate analyses, heat of combustion, forms of sulfur, ash-fusion temperatures, free-swelling index, and real specific-gravity determinations for 12 coal samples from Virginia and West Virginia

3. Major and minor oxide and trace-element composition of the laboratory ash of 12 coal samples from Virginia and West Virginia

4. Arithmetic mean, observed range, geometric mean, and geometric deviation of ash content and contents of 11 major and minor oxides in the laboratory ash of 12 coal samples from Virginia and West Virginia

5. Average abundance of chemical elements and oxides in 12 whole coal and ash samples from Virginia and West Virginia compared with 331 Appalachian region and 509 bituminous coal samples

6. Major-, minor-, and trace-element composition of 12 coal samples from Virginia and West Virginia on a whole-coal basis

7. Arithmetic mean, observed range, geometric mean, and geometric deviation of 38 elements in 12 coal samples from Virginia and West Virginia

8. Petrographic analyses of two coal samples from McDowell County, W. Va., and Tazewell County, Va.

9. Reflectance and fixed-carbon values for 12 coal samples from McDowell County, W. Va., and Tazewell County, Va. 


\title{
Chemical Analyses and Physical Properties of 12 Coal Samples from the Pocahontas Field, Tazewell County, Virginia, and McDowell County, West Virginia
}

\author{
By Virgil A. Trent, Jack H. Medlin, S. Lynn Coleman, and \\ RONALD W. STANTON \\ ABSTRACT
}

Modern coal-quality data and geologic field observations are interpreted in terms of the coal geology in a small area near Pocahontas, Va. Detailed chemical analyses and physical-property determinations of 12 channel-coal samples (reported on whole-coal and laboratory ash basis) indicate that the coals are mostly of high coking quality, low in sulfur, and low in ash. Major-, minor-, and trace-element analyses indicate no anomalous quantities or environmentally deleterious amounts of roughly 70 elements and elemental oxides. The five coal beds sampled from the Lower Pennsylvanian span the medium-volatile bituminous coal rank class. The rank and metamorphic grade of the coals are postulated to increase because of high pressure and temperature gradients associated with two processes: depth of burial through geologic time and structural deformation. This is evidenced in variations of fixed carbon and vitrinite reflectance values between coal beds and within single coal beds. It is concluded that load metamorphism due to the depth of burial advanced the coal ranks to the rank of medium-volatile bituminous coal; further advancement through the medium-volatile coal rank required additional pressures and temperatures that resulted from local and regional folding.

Stratigraphic and lithologic studies suggest that the Pennsylvanian sea for the most part was regressing northwestward and that the coal beds were deposited in a coastal plain-deltaic environment.

Combustion engineers will need similar coal-quality data to design powerplants for future energy production. These coal-quality data are available from the National Coal Resources Data System (NCRDS), U.S. Geological Survey, Reston, Va. 22092.

\section{INTRODUCTION}

Energy-resource studies have been undertaken by the U.S. Geological Survey for the purpose of assessing coal quality and quantity in the central Appalachian Basin. Coal bed sampling is an integral part of these studies. During these investigations, while mapping the geology of the Anawalt $7 \frac{1}{1} 2$-minute quadrangle in southern West Virginia and southwestern Virginia, 12 coal bed channel samples were collected. The purpose of this report is to present the results of the chemical analyses and physical tests performed on these coal samples, and to interpret these data and the field observations in terms of the coal geology. 


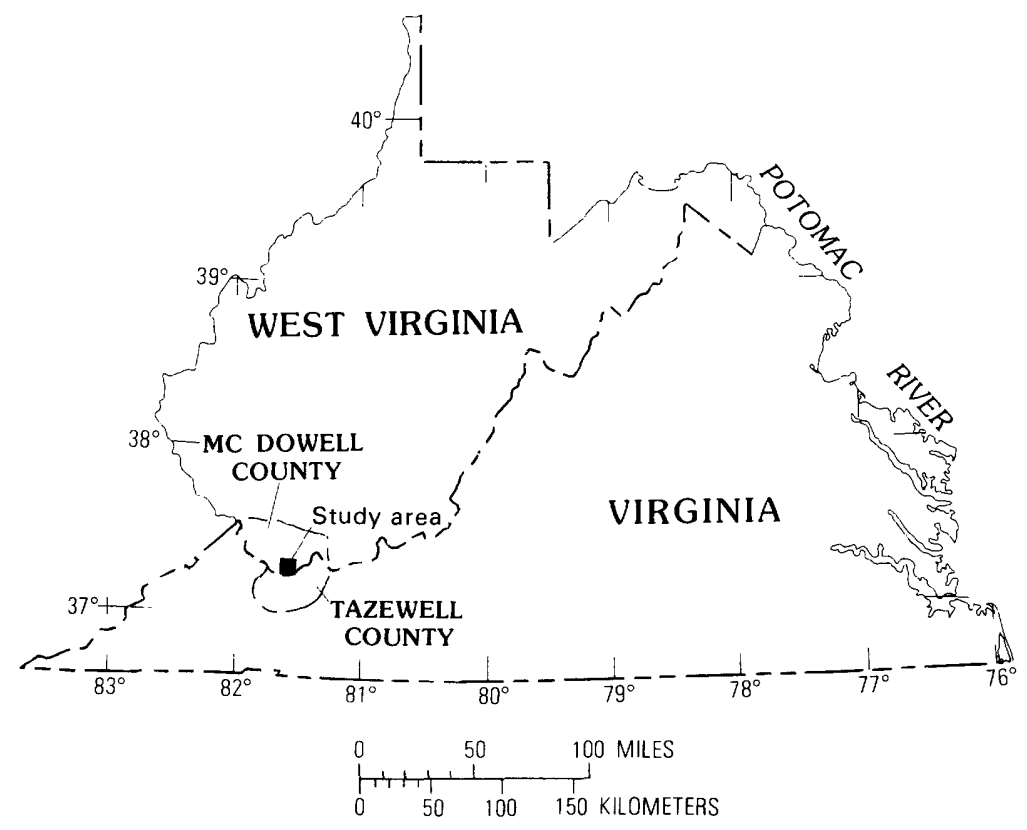

Figure 1.-Index map showing location of study area in West Virginia and Virginia.

\section{GEOGRAPHIC SETTING}

Most of the sampled area shown in plate 1 is in the southwest corner of the Anawalt quadrangle at lat $37^{\circ} 15^{\prime} \mathrm{N}$., long $81^{\circ} 30^{\prime} \mathrm{W}$. The study area is situated approximately at the head of the Tug Fork River between Monson and Jenkinjones, McDowell County, W. Va. The rectangular study area encompasses approximately $54 \mathrm{~km}^{2}$ (about $20 \mathrm{mi}^{2}$ ) including small parts of the adjacent Tiptop, Tazewell North, and Gary $71 / 2$-minute quadrangles. The Virginia-West Virginia boundary line runs generally southwestward through the area along Big Stone Ridge which divides the area into separate drainage basins. McDowell County, W. Va., is situated north of Big Stone Ridge and Tazewell County, Va., is south.

\section{SCOPE OF PRESENT STUDY}

The area being investigated continues to be an important coalmining center; it is located $10 \mathrm{~km}$ or about $6 \mathrm{mi}$ west-southwest of Pocahontas, Va., in the Pocahontas coal field (Trumbull, 1960). We 
collected 12 coal samples in this area for test purposes while mapping the geology. The ultimate aim of this investigation is to present modern chemical and physical property data and to interpret the results in accordance with the findings in the field.

The 12 coal channel samples were obtained from 5 coal beds that span about $244 \mathrm{~m}$ or $800 \mathrm{ft}$ of stratigraphic section in the Pocahontas and New River Formations of Early Pennsylvanian age. To insure the acquisition of fresh unoxidized coal, most of these samples were collected from active mining operations. Sometimes coal samples were collected from pillars in inactive parts of underground mines; nevertheless, the full coal bed thickness was faced-up to expose fresh coal. Four of the 12 samples are from strip-mine operations and seven are from underground mines. One sample, VAT- 6 , was faced-up by a bulldozer at a surface bench exposure near a new deep mine development.

Sampling procedures discussed by Schopf (1960, p. 49-52) and the guidelines presented by Swanson and Huffman (1976, p. 1-3) were used. The coal beds were sampled through their complete thicknesses. The channel cut was about $7 \mathrm{~cm}$ deep (nearly $3 \mathrm{in}$ ) and $10 \mathrm{~cm}$ wide (about $4 \mathrm{in}$ ) providing about $2.5 \mathrm{~kg}$ (about $5.5 \mathrm{lb}$ ) of coal per foot of coal bed thickness. The samples were pulverized at the collection site to less than 1.3-cm (0.5-in) size and then packed in plastic bags to prevent loss of bed moisture during shipment. This procedure also eliminated possible trace-metal contamination from cans or cloth bags. Coal bed partings of clay, rock, or other impurities more than $1 \mathrm{~cm}$ (or about 0.4 in) thick were excluded from the samples.

\section{PREVIOUS INVESTIGATIONS}

The first published report on the coal geology of the Pocahontas coal field was compiled by Captain Isaiah A. Welch (1896) on the basis of field investigations he began in 1873. Commercial coal mining began in the district in 1892. Then, Marius R. Campbell, U.S. Geological Survey, mapped the geology and discussed the coal resources in two classic reports, the Pocahontas Folio (1896) and the Tazewell Folio (1897), which include the map area. Campbell's work, which is based upon excellent reconnaissance scale geologic mapping, reports the stratigraphic and structural framework for the Pocahontas region.

The next geologic report on the area was an intermediate-scale $(1: 63,360)$ regional geologic map of Wyoming and McDowell Counties, W. Va. (Hennen and Gawthrop, 1915). This report covered the northern part of our study area; it showed most of the Pocahontas coal field, including the most important coal beds, and indicated the structure of the Pocahontas No. 3 and Sewell coal beds by contour lines. Most of the data presented were coal-resource estimates by bed that were derived 
from company drilling information, measured coal sections, and outcrop examinations. Detailed stratigraphic sections of the Kanawha, New River, and Pocahontas Formations were compiled using measured sections and company drilling and prospecting information. Thus, compilation of the sections from scattered locations in the twocounty area into a best-fit stratigraphic column was a significant advance in the geology of the area.

An important report by Harnsberger (1919) discusses the coal geology in the southern part of the study area. Harnsberger published a geologic map at 1 mile to the inch $(1: 63,360)$ and compiled stratigraphic sections for the area. He also correlated the coal beds in the Horsepen Creek and Laurel Fork drainage basins with coal beds in the upper Tug Fork drainage basin of McDowell County, W. Va.

"The Geology of the Bramwell quadrangle, West Virginia-Virginia" (Englund, 1968) is the most recent and thorough geologic map published on this region. The Bramwell 71/2-minute quadrangle is located east of and adjacent to the Anawalt quadrangle. The geologic map, based on detailed geologic mapping $(1: 24,000)$, with text and crosssections, presents modern stratigraphic and structural data for the Pocahontas area.

\section{ACKNOWLEDGMENTS}

Most of the data contained in this report results from cooperative efforts by numerous industry employees and government workers. The standard ultimate and proximate coal analyses and density determinations were completed by the Coal Analysis Section, Department of Energy (formerly of the Bureau of Mines), under the supervision of Mr. Forrest E. Walker, Chemist-in-Charge. In addition to these analyses, the coal samples were also chemically analyzed by means of a variety of techniques for major-, minor-, and trace-element contents by personnel of the U.S. Geological Survey. The analysts and sample preparators provided a major contribution to this report.

We wish to thank Mr. J. E. Caffrey, Chief Mining Engineer, Gary District, U.S. Steel Corporation, and Mr. Jack J. Morefield, Superintendent, Jenkinjones mine, Pocahontas Fuels Company, for their assistance and permission to collect the coal samples on mining properties under their supervision.

\section{GEOLOGICAL SETTING}

\section{STRATIGRAPHY}

Bedded rock of Early Pennsylvanian and Late Mississippian age underlies the rectangular $54 \mathrm{~km}^{2}$ study area (pl. 1) in southern West Virginia and southwestern Virginia. Sandstone, siltstone, shale, mud- 
stone, limestone, and coal are the principal rocks in the area of investigation. The 12 coal-channel samples discussed in this report are from five coal beds in the New River and Pocahontas Formations of Early Pennsylvanian age (Englund, 1968). A generalized stratigraphic column for the study area is presented in plate 2 . The coal bed nomenclature and correlations are based on published data (Hennen and Gawthrop, 1915; Harnsberger, 1919; Englund, 1968), on company mine data, and on geologic mapping. Most of the study area is underlain by the coal-bearing New River and Pocahontas Formations; however, older formations are exposed southeast of Laurel Fork in and along the margins of Abbs Valley near the Allegheny Front. A geologic map with profile section of the study area is shown in plate 3. Successively older Upper Mississippian formations-Bluestone, Hinton, and Bluefield Formations and the Greenbrier Limestone-are confined mainly to the southeastern part of the area (see pl. 3). Abbs Valley for instance is underlain by the Greenbrier Limestone, the oldest rock unit in the study area, which results in an interior drainage system marked by sink-hole topography.

\section{STRUCTURE}

The area of investigations is mostly underlain by low-dipping coalbearing strata that form a broad open fold called the Pocahontas syncline (Harnsberger, 1919, p. 37; Englund, 1968). The syncline plunges southwestward at a low angle (50-100 feet per mile) from Pocahontas to Bishop, Va. Flanking the syncline on the north side is a major regional fold, the Dry Fork anticline (Harnsberger, 1919, p. 36; Hennen and Gawthrop, 1915, p. 41-42), whose axis trends eastnortheast through the middle of the Anawalt quadrangle. The coal beds suddenly thin and become irregular in the southern part of the study area where they abruptly increase in dip to the northwest (pl. 3) along the south limb of the Pocahontas syncline. This is believed to be a result of original diminution of the coal beds rather than tectonic thinning by deformation. This zone, a short distance southeast of Laurel Fork and generally parallel to it, marks the Allegheny Front where the coal-bearing strata are terminated to the southeast. Another large regional fold, the Abbs Valley anticline (Harnsberger, 1919, p. 37), is located south of the front in the southeastern part of the study area. Here, the Greenbrier Limestone of Late Mississippian age (Englund, 1968) crops out in Abbs Valley in the core of the breached anticline. Younger Mississippian formations are found in narrow bands of outcrop along the ridges and hills parallel to Abbs Valley. Previous workers have interpreted the sheared and jointed rock along the structural front as a fault(s), but we observed no displacement in mappable rock units along the margins of the fold. 


\section{METAMORPHISM}

In the area being investigated several petrologic indicators of increasing deformational stress were observed. Fold development in the district intensified to the southeast toward the Allegheny Front where jointing and fracturing are evident in the outcropping strata. Growth flakes of muscovite which we interpret as having formed under stress are found commonly throughout carbonaceous beds of sandstone, siltstone, and shale.

Large-scale spheroidal features are prominent in the roof shale, siltstone, and sandstone exposed along the highwalls of strip-mined coal beds in the Pocahontas and New River Formations. The structural features developed in certain rock types as the result of differential shearing forces that accompanied an episode of major folding. These ovoid protrusions in the highwall exposures are better developed and increase in size toward the axial plane of the Dry Fork anticline. Lower in the stratigraphic section clayey siltstone beds of the Bluestone Formation are recrystallized and thus have a phyllitic sheen; some sandstone beds in the Hinton Formation are metamorphosed to quartzite.

Very hard or tough coal, which is further evidence of higher metamorphic grade, typifies some of the coal beds in the study area. The increase in fixed carbon values of the coal beds as depth increases is a positive indication of increase in coal rank. Most of the features previously cited were developed because of folding stresses. However, depth of burial probably was a principal factor in advancing the rank of the coals at least to the medium-volatile bituminous rank class.

\section{CHEMICAL COMPOSITION}

In the present study, five coal beds, intermittently spaced through $244 \mathrm{~m}$ or about $800 \mathrm{ft}$ of strata, were sampled at 12 mine locations (pl. 1). A flow sheet (fig. 2) shows the sequence of sample preparation and chemical analysis as outlined by Swanson and Huffman (1976, p. 5). The reported chemical analyses are made up of two principal parts:

- U.S. Department of Energy standard coal analyses which include ultimate and proximate analyses, forms of sulfur, and calorific value (Btu per pound) determinations.

- U.S. Geological Survey determinations of the major-, minor-, and trace-element concentrations in coal samples on a whole-coal basis; and the major and minor oxides and trace-element contents in the laboratory ash of the coal samples.

Analytical results for the 12 coal samples are listed in tables 1, 3, and 6 in the stratigraphic order of the coals, youngest to oldest. Where 


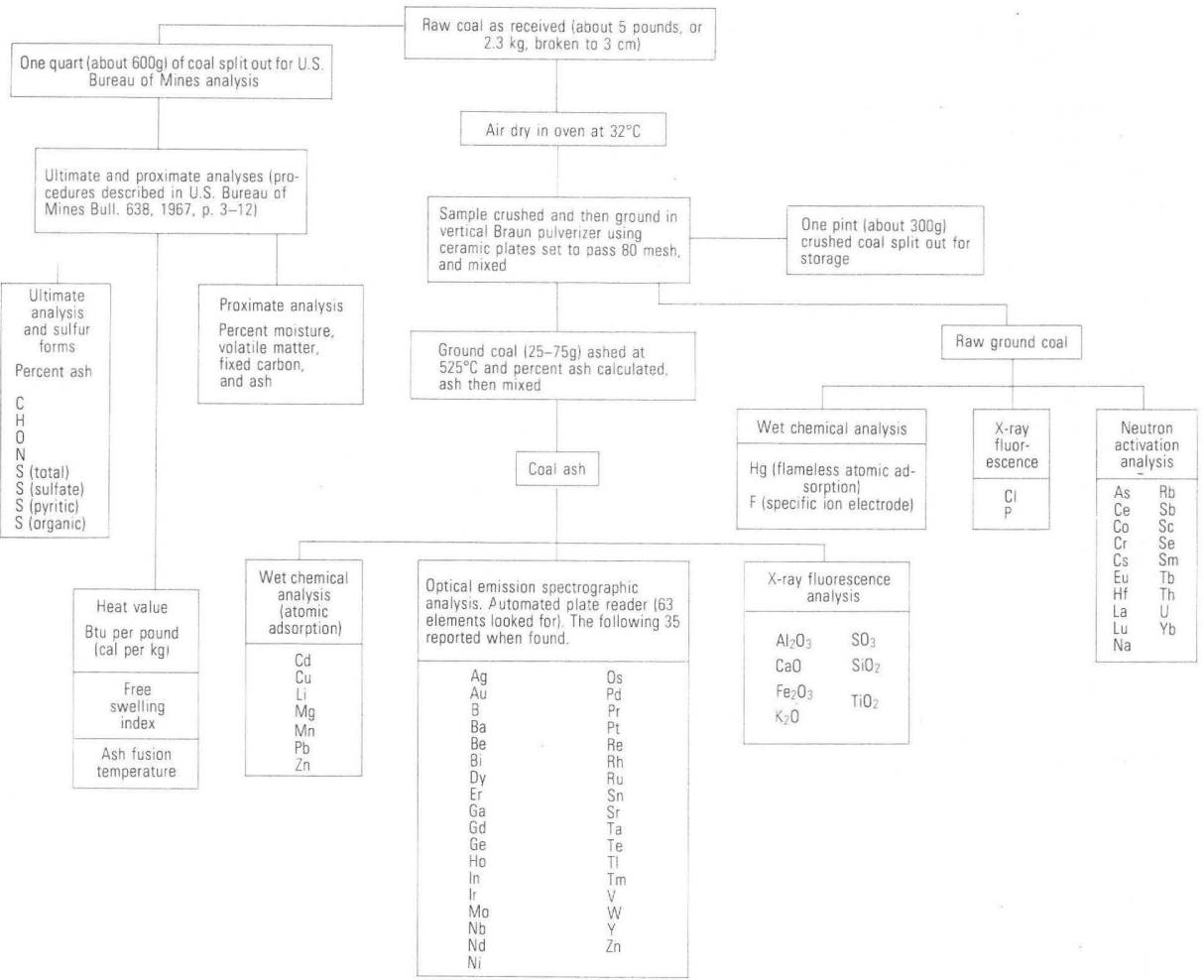

FIGURE 2.-Flowsheet of sample preparation and chemical analysis of coal.

there is more than one sample for a single coal bed, the samples are arranged in order of increasing fixed-carbon values.

\section{U.S. DEPARTMENT OF ENERGY STANDARD COAL ANALYSIS}

The U.S. Department of Energy ultimate and proximate coal analyses for the 12 channel samples are presented in table 1 . If we use the appropriate Parr formulas for classification according to rank, the coals from which the 12 samples were collected can be assigned to the medium-volatile bituminous coal rank class. The fixed-carbon, volatile matter, and calorific values were calculated to the mineralmatter-free basis (American Society for Testing and Materials, 1974, pt. 26, p. 54-58). The coals are generally low in sulfur and ash and are mostly of high coking quality; low-sulfur and low-ash coals contain less than 1 percent sulfur and less than 8 percent ash. The samples indicate that the coals span the medium-volatile bituminous coal rank class; three of the samples are within 0.5 percent fixed carbon of being 
TABLE 1.-Proximate and ultimate analyses, heat content, forms of sulfur, free-swelling from Virginia and

[Each sample represents the entire thickness of the coal bed and the beds are in stratigraphic order-youngest to gravity are in percent. For each sample the analyses are reported three ways: as received, moisture free, and moisof Mines (now included in the Department of Energy), Pittsburgh, $\mathrm{Pa}$.]

\begin{tabular}{|c|c|c|c|c|c|c|c|c|c|c|c|}
\hline \multirow{2}{*}{$\begin{array}{l}\text { Field } \\
\text { sample } \\
\text { number }\end{array}$} & \multicolumn{4}{|c|}{ Proximate analysis } & \multicolumn{4}{|c|}{ Ultimate analysis } & \multicolumn{3}{|c|}{ Heat of combustion } \\
\hline & Moisture $^{1}$ & $\begin{array}{l}\text { Volatile } \\
\text { matter }\end{array}$ & $\begin{array}{c}\text { Fixed } \\
\text { carbon }\end{array}$ & Ash & Hydrogen & Carbon & Nitrogen & Oxygen & Sulfur & $\mathrm{Kcal} / \mathrm{kg}$ & $\mathrm{Btu} / \mathrm{lb}$ \\
\hline $\begin{array}{l}\text { VAT-1 } \\
\text { (w187040). }\end{array}$ & $\begin{array}{l}2.1 \\
-- \\
--\end{array}$ & $\begin{array}{l}26.2 \\
26.8 \\
29.6\end{array}$ & $\begin{array}{l}62.3 \\
63.6 \\
70.4\end{array}$ & $\begin{array}{l}9.4 \\
9.6 \\
--\end{array}$ & $\begin{array}{l}4.8 \\
4.7 \\
5.2\end{array}$ & $\begin{array}{l}78.4 \\
80.1 \\
88.6\end{array}$ & $\begin{array}{l}1.4 \\
1.4 \\
1.6\end{array}$ & $\begin{array}{l}5.2 \\
3.4 \\
3.8\end{array}$ & $\begin{array}{r}0.8 \\
.8 \\
.9\end{array}$ & $\begin{array}{l}7,690 \\
7,860 \\
8,690\end{array}$ & $\begin{array}{l}13,850 \\
14,150 \\
15,650\end{array}$ \\
\hline $\begin{array}{l}\text { JHM-54 } \\
\text { (d170150). }\end{array}$ & $\begin{array}{r}.9 \\
-- \\
--\end{array}$ & $\begin{array}{l}27.8 \\
28.1 \\
29.2\end{array}$ & $\begin{array}{l}67.4 \\
68.0 \\
70.8\end{array}$ & $\begin{array}{l}3.9 \\
3.9 \\
--\end{array}$ & $\begin{array}{l}5.0 \\
4.9 \\
5.1\end{array}$ & $\begin{array}{l}85.3 \\
86.1 \\
89.6\end{array}$ & $\begin{array}{l}1.4 \\
1.4 \\
1.5\end{array}$ & $\begin{array}{l}3.9 \\
3.1 \\
3.3\end{array}$ & $\begin{array}{l}.5 \\
.5 \\
.5\end{array}$ & $\begin{array}{l}8,330 \\
8,410 \\
8,750\end{array}$ & $\begin{array}{l}15,000 \\
15,140 \\
15,760\end{array}$ \\
\hline $\begin{array}{l}\text { VAT-3 } \\
\text { (w187042). }\end{array}$ & $\begin{array}{l}3.0 \\
-- \\
--\end{array}$ & $\begin{array}{l}25.1 \\
25.9 \\
28.5\end{array}$ & $\begin{array}{l}63.0 \\
64.9 \\
71.5\end{array}$ & $\begin{array}{l}8.9 \\
9.2 \\
--\end{array}$ & $\begin{array}{l}4.8 \\
4.6 \\
5.1\end{array}$ & $\begin{array}{l}78.6 \\
81.0 \\
89.2\end{array}$ & $\begin{array}{l}1.4 \\
1.4 \\
1.6\end{array}$ & $\begin{array}{l}5.7 \\
3.1 \\
3.4\end{array}$ & $\begin{array}{l}.6 \\
.6 \\
.7\end{array}$ & $\begin{array}{l}7,660 \\
7,890 \\
8,690\end{array}$ & $\begin{array}{l}13,780 \\
14,210 \\
15,640\end{array}$ \\
\hline $\begin{array}{l}\text { JHM-55 } \\
\text { (d170151). }\end{array}$ & $\begin{array}{l}1.7 \\
-- \\
--\end{array}$ & $\begin{array}{l}25.1 \\
25.5 \\
27.9\end{array}$ & $\begin{array}{l}64.9 \\
66.0 \\
72.1\end{array}$ & $\begin{array}{l}8.3 \\
8.4 \\
--\end{array}$ & $\begin{array}{l}4.8 \\
4.7 \\
5.1\end{array}$ & $\begin{array}{l}79.8 \\
81.2 \\
88.7\end{array}$ & $\begin{array}{l}1.3 \\
1.3 \\
1.4\end{array}$ & $\begin{array}{l}5.3 \\
3.9 \\
4.2\end{array}$ & $\begin{array}{l}.5 \\
.5 \\
.6\end{array}$ & $\begin{array}{l}7,770 \\
7,910 \\
8,640\end{array}$ & $\begin{array}{l}13,990 \\
14,230 \\
15,540\end{array}$ \\
\hline $\begin{array}{l}\text { VAT-5 } \\
\text { (w191521). }\end{array}$ & $\begin{array}{l}2.8 \\
-- \\
--\end{array}$ & $\begin{array}{l}26.8 \\
27.6 \\
28.8\end{array}$ & $\begin{array}{l}66.1 \\
68.0 \\
71.2\end{array}$ & $\begin{array}{l}4.3 \\
4.4 \\
--\end{array}$ & $\begin{array}{l}5.1 \\
4.9 \\
5.2\end{array}$ & $\begin{array}{l}82.0 \\
84.4 \\
88.3\end{array}$ & $\begin{array}{l}1.2 \\
1.2 \\
1.3\end{array}$ & $\begin{array}{l}6.6 \\
4.2 \\
4.4\end{array}$ & $\begin{array}{l}.8 \\
.8 \\
.9\end{array}$ & $\begin{array}{l}8,020 \\
8,250 \\
8,630\end{array}$ & $\begin{array}{l}14,430 \\
14,850 \\
15,530\end{array}$ \\
\hline $\begin{array}{l}\text { JHM-56 } \\
\text { (d170152). }\end{array}$ & $\begin{array}{l}1.9 \\
-- \\
--\end{array}$ & $\begin{array}{l}24.8 \\
25.3 \\
26.2\end{array}$ & $\begin{array}{l}69.7 \\
71.0 \\
73.8\end{array}$ & $\begin{array}{l}3.6 \\
3.7 \\
--\end{array}$ & $\begin{array}{l}5.0 \\
4.9 \\
5.1\end{array}$ & $\begin{array}{l}84.3 \\
85.9 \\
89.2\end{array}$ & $\begin{array}{l}1.2 \\
1.2 \\
1.3\end{array}$ & $\begin{array}{l}4.8 \\
3.2 \\
3.3\end{array}$ & $\begin{array}{l}1.1 \\
1.1 \\
1.2\end{array}$ & $\begin{array}{l}8,190 \\
8,350 \\
8,670\end{array}$ & $\begin{array}{l}14,740 \\
15,030 \\
15,600\end{array}$ \\
\hline $\begin{array}{l}\text { VAT-6 } \\
\text { (w191522). }\end{array}$ & $\begin{array}{l}6.2 \\
-- \\
--\end{array}$ & $\begin{array}{l}22.5 \\
24.0 \\
27.3\end{array}$ & $\begin{array}{l}59.9 \\
63.9 \\
72.7\end{array}$ & $\begin{array}{r}11.4 \\
12.2 \\
--\end{array}$ & $\begin{array}{l}4.5 \\
4.1 \\
4.6\end{array}$ & $\begin{array}{l}70.8 \\
75.5 \\
85.9\end{array}$ & $\begin{array}{l}1.0 \\
1.1 \\
1.2\end{array}$ & $\begin{array}{r}11.7 \\
6.6 \\
7.5\end{array}$ & $\begin{array}{l}.6 \\
.6 \\
.7\end{array}$ & $\begin{array}{l}6,740 \\
7,180 \\
8,180\end{array}$ & $\begin{array}{l}12,130 \\
12,930 \\
14,720\end{array}$ \\
\hline $\begin{array}{l}\text { VAT-4 } \\
\text { (w187043). }\end{array}$ & $\begin{array}{l}4.9 \\
-- \\
--\end{array}$ & $\begin{array}{l}24.0 \\
25.2 \\
26.6\end{array}$ & $\begin{array}{l}66.3 \\
69.7 \\
73.4\end{array}$ & $\begin{array}{l}4.8 \\
5.0 \\
--\end{array}$ & $\begin{array}{l}5.1 \\
4.8 \\
5.0\end{array}$ & $\begin{array}{l}81.3 \\
85.5 \\
90.0\end{array}$ & $\begin{array}{l}1.2 \\
1.3 \\
1.3\end{array}$ & $\begin{array}{l}6.9 \\
2.7 \\
2.8\end{array}$ & $\begin{array}{l}.7 \\
.7 \\
.8\end{array}$ & $\begin{array}{l}7,920 \\
8,330 \\
8,770\end{array}$ & $\begin{array}{l}14,260 \\
14,990 \\
15,790\end{array}$ \\
\hline $\begin{array}{l}\text { JHM-59 } \\
\text { (d170155). }\end{array}$ & $\begin{array}{l}2.2 \\
-- \\
--\end{array}$ & $\begin{array}{l}21.3 \\
21.8 \\
22.8\end{array}$ & $\begin{array}{l}72.3 \\
73.9 \\
77.2\end{array}$ & $\begin{array}{l}4.2 \\
4.3 \\
--\end{array}$ & $\begin{array}{l}4.8 \\
4.7 \\
4.9\end{array}$ & $\begin{array}{l}84.1 \\
86.0 \\
89.9\end{array}$ & $\begin{array}{l}1.3 \\
1.3 \\
1.4\end{array}$ & $\begin{array}{l}5.1 \\
3.2 \\
3.4\end{array}$ & $\begin{array}{l}.5 \\
.5 \\
.5\end{array}$ & $\begin{array}{l}8,140 \\
8,330 \\
8,700\end{array}$ & $\begin{array}{l}14,660 \\
14,990 \\
15,660\end{array}$ \\
\hline $\begin{array}{l}\text { VAT-2 } \\
\text { (w187041). }\end{array}$ & $\begin{array}{l}2.4 \\
-- \\
--\end{array}$ & $\begin{array}{l}22.9 \\
23.5 \\
25.1\end{array}$ & $\begin{array}{l}68.3 \\
70.0 \\
74.9\end{array}$ & $\begin{array}{l}6.4 \\
6.6 \\
--\end{array}$ & $\begin{array}{l}4.7 \\
4.5 \\
4.9\end{array}$ & $\begin{array}{l}81.7 \\
83.7 \\
89.6\end{array}$ & $\begin{array}{l}1.2 \\
1.2 \\
1.3\end{array}$ & $\begin{array}{l}5.4 \\
3.3 \\
3.6\end{array}$ & $\begin{array}{l}.6 \\
.6 \\
.7\end{array}$ & $\begin{array}{l}7,950 \\
8,150 \\
8,720\end{array}$ & $\begin{array}{l}14,310 \\
14,660 \\
15,690\end{array}$ \\
\hline $\begin{array}{l}\text { JHM-57 } \\
\text { (d170153). }\end{array}$ & $\begin{array}{l}1.9 \\
-- \\
--\end{array}$ & $\begin{array}{l}20.8 \\
21.2 \\
23.0\end{array}$ & $\begin{array}{l}69.7 \\
71.0 \\
77.0\end{array}$ & $\begin{array}{l}7.6 \\
7.7 \\
--\end{array}$ & $\begin{array}{l}4.5 \\
4.4 \\
4.7\end{array}$ & $\begin{array}{l}81.1 \\
82.7 \\
89.6\end{array}$ & $\begin{array}{l}1.1 \\
1.1 \\
1.2\end{array}$ & $\begin{array}{l}5.2 \\
3.6 \\
3.9\end{array}$ & $\begin{array}{l}.5 \\
.5 \\
.6\end{array}$ & $\begin{array}{l}7,760 \\
7,910 \\
8,580\end{array}$ & $\begin{array}{l}13,970 \\
14,240 \\
15,440\end{array}$ \\
\hline $\begin{array}{l}\text { JHM-58 } \\
\text { (d170154). }\end{array}$ & $\begin{array}{l}2.6 \\
-- \\
--\end{array}$ & $\begin{array}{l}21.0 \\
21.6 \\
22.6\end{array}$ & $\begin{array}{l}72.1 \\
74.0 \\
77.4\end{array}$ & $\begin{array}{l}4.3 \\
4.4 \\
--\end{array}$ & $\begin{array}{l}4.8 \\
4.6 \\
4.8\end{array}$ & $\begin{array}{l}83.9 \\
86.1 \\
90.1 \\
\end{array}$ & $\begin{array}{l}1.2 \\
1.2 \\
1.3\end{array}$ & $\begin{array}{l}5.2 \\
3.0 \\
3.1\end{array}$ & $\begin{array}{l}.6 \\
.6 \\
.6\end{array}$ & $\begin{array}{l}8,060 \\
8,280 \\
8,660\end{array}$ & $\begin{array}{l}14,510 \\
14,900 \\
15,590\end{array}$ \\
\hline
\end{tabular}

'Original moisture content may be slightly more than shown because samples were collected and transported in plastic bags to avoid metal contamination.

low-volatile bituminous coal. The fixed-carbon and volatile matter values of the coal samples range from 71 to 78 percent and from 29 to 22 percent respectively, from younger to older beds.

The arithmetic-mean values for the 12 coal samples, shown in table 2 , on an "as received basis" are 2.7 percent moisture, 6.4 percent ash, 0.7 percent sulfur, and 14,140 Btu/lb (equals 7,856.2 kcal/kg). No clear relation is apparent between the moisture, ash, and calorific values and the stratigraphic position of the sampled coal beds. However, a noteworthy aspect of the analytical results is the identification of highquality metallurgical coal(s).

\section{SULFUR CONTENT}

The amount of sulfur in the 12 coal samples is low, generally less than 1 percent. On the basis of the chemical analyses, most of the 
index, ash-fusion temperature, and specific-gravity determinations for 12 coal samples West Virginia

oldest. All analyses except kilocalorie per kilogram, Btu, free-swelling index, ash-fusion temperatures, and specific ture and ash free. Laboratory numbers are in parentheses. All analyses are by the Coal Analyses Section, U.S. Bureau

\begin{tabular}{|c|c|c|c|c|c|c|c|c|c|c|}
\hline \multirow[b]{2}{*}{$\begin{array}{l}\text { Field } \\
\text { sample } \\
\text { number }\end{array}$} & \multirow[b]{2}{*}{$\begin{array}{l}\text { Air-dried } \\
\text { loss }\end{array}$} & \multicolumn{3}{|c|}{ Forms of sulfur } & \multirow[b]{2}{*}{$\begin{array}{c}\text { Free } \\
\text { swelling }\end{array}$} & \multicolumn{3}{|c|}{ Ash fusion temperature ${ }^{\circ} \mathrm{C}$} & \multirow[b]{2}{*}{$\begin{array}{l}\text { Real } \\
\text { specific } \\
\text { gravity }\end{array}$} & \multirow[b]{2}{*}{$\begin{array}{c}\text { Coal } \\
\text { bed }\end{array}$} \\
\hline & & Sulfate & Pyritic & Organic & & $\begin{array}{l}\text { Initial } \\
\text { deform- } \\
\text { ation }\end{array}$ & Softening & Fluid & & \\
\hline $\begin{array}{l}\text { VAT-1 } \\
\text { (w187040). }\end{array}$ & $\begin{array}{c}19.8 \\
-- \\
--\end{array}$ & $\begin{array}{r}0.01 \\
.01 \\
.01\end{array}$ & $\begin{array}{r}0.34 \\
.35 \\
.38\end{array}$ & $\begin{array}{r}0.40 \\
.41 \\
.45\end{array}$ & 7.0 & 1,470 & 1,500 & 1,530 & 1.36 & $\begin{array}{l}\text { Upper Horsepen } \\
\text { (Smith Seam) }\end{array}$ \\
\hline $\begin{array}{l}\text { JHM-54 } \\
\text { (d170150). }\end{array}$ & $\begin{array}{c}.0 \\
-- \\
--\end{array}$ & $\begin{array}{l}.01 \\
.01 \\
.01\end{array}$ & $\begin{array}{l}.09 \\
.09 \\
.09\end{array}$ & $\begin{array}{l}.41 \\
.41 \\
.43\end{array}$ & 7.0 & 1,320 & 1,355 & 1,390 & 1.32 & Do. \\
\hline $\begin{array}{l}\text { VAT-3 } \\
\text { (w187042). }\end{array}$ & $\begin{array}{l}9.9 \\
-- \\
--\end{array}$ & $\begin{array}{l}.07 \\
.07 \\
.08\end{array}$ & $\begin{array}{l}.08 \\
.08 \\
.09\end{array}$ & $\begin{array}{l}.50 \\
.52 \\
.57\end{array}$ & 8.0 & 1,600 & $1,600 \mathrm{G}$ & $1,600 \mathrm{G}^{2}$ & 1.37 & Do. \\
\hline $\begin{array}{l}\text { JHM-55 } \\
\text { (d170151). }\end{array}$ & $\begin{array}{c}.0 \\
-- \\
--\end{array}$ & $\begin{array}{l}.04 \\
.04 \\
.04\end{array}$ & $\begin{array}{l}.09 \\
.09 \\
.10\end{array}$ & $\begin{array}{l}.41 \\
.42 \\
.46\end{array}$ & 8.5 & 1,600 & $1,600 \mathrm{G}$ & $1,600 \mathrm{G}^{2}$ & 1.35 & Do. \\
\hline $\begin{array}{l}\text { VAT-5 } \\
\text { (w191521). }\end{array}$ & $\begin{array}{l}.0 \\
-- \\
--\end{array}$ & $\begin{array}{l}.13 \\
.13 \\
.14\end{array}$ & $\begin{array}{l}.11 \\
.11 \\
.12\end{array}$ & $\begin{array}{l}.55 \\
.57 \\
.59\end{array}$ & 9.0 & 1,290 & 1,320 & 1,375 & 1.34 & War Creek \\
\hline $\begin{array}{l}\text { JHM-56 } \\
\text { (d170152). }\end{array}$ & $\begin{array}{c}.0 \\
-- \\
--\end{array}$ & $\begin{array}{l}.04 \\
.04 \\
.04\end{array}$ & $\begin{array}{l}.43 \\
.44 \\
.46\end{array}$ & $\begin{array}{l}.64 \\
.65 \\
.68\end{array}$ & 9.0 & 1,170 & 1,225 & 1,340 & 1.33 & Lower Horsepen \\
\hline $\begin{array}{l}\text { VAT-6 } \\
\text { (w191522). }\end{array}$ & $\begin{array}{l}.0 \\
-- \\
--\end{array}$ & $\begin{array}{l}.04 \\
.04 \\
.05\end{array}$ & $\begin{array}{l}.05 \\
.05 \\
.06\end{array}$ & $\begin{array}{l}.49 \\
.52 \\
.59\end{array}$ & 1.5 & 1,350 & 1,405 & 3,495 & 1.43 & Pocahontas No. 4 \\
\hline $\begin{array}{l}\text { VAT-4 } \\
\text { (w187043). }\end{array}$ & $\begin{array}{c}10.5 \\
-- \\
--\end{array}$ & $\begin{array}{l}.01 \\
.01 \\
.01\end{array}$ & $\begin{array}{l}.16 \\
.17 \\
.18\end{array}$ & $\begin{array}{l}.54 \\
.57 \\
.60\end{array}$ & 9.0 & 1,230 & 1,290 & 1,455 & 1.32 & Do. \\
\hline $\begin{array}{l}\text { JHM-59 } \\
\text { (d170155). }\end{array}$ & $\begin{array}{c}.0 \\
-- \\
--\end{array}$ & $\begin{array}{l}.01 \\
.01 \\
.01\end{array}$ & $\begin{array}{l}.04 \\
.04 \\
.04\end{array}$ & $\begin{array}{l}.45 \\
.46 \\
.48\end{array}$ & 9.0 & 1,200 & 1,230 & 1,280 & 1.33 & Do. \\
\hline $\begin{array}{l}\text { VAT-2 } \\
\text { (w187041). }\end{array}$ & $\begin{array}{c}10.3 \\
-- \\
--\end{array}$ & $\begin{array}{l}.01 \\
.01 \\
.01\end{array}$ & $\begin{array}{l}.07 \\
.07 \\
.08\end{array}$ & $\begin{array}{l}.57 \\
.58 \\
.62\end{array}$ & 9.0 & 1,140 & 1,165 & 1,195 & 1.34 & Pocahontas No. 3 \\
\hline $\begin{array}{l}\text { JHM-57 } \\
\text { (d170153). }\end{array}$ & $\begin{array}{l}.0 \\
-- \\
--\end{array}$ & $\begin{array}{l}.02 \\
.02 \\
.02\end{array}$ & $\begin{array}{l}.04 \\
.04 \\
.04\end{array}$ & $\begin{array}{l}.44 \\
.45 \\
.49\end{array}$ & 9.0 & 1,295 & 1,320 & 1,350 & 1.34 & Do. \\
\hline $\begin{array}{l}\text { JHM-58 } \\
\text { (d170154). }\end{array}$ & $\begin{array}{c}.0 \\
-- \\
--\end{array}$ & $\begin{array}{l}.01 \\
.01 \\
.01\end{array}$ & $\begin{array}{l}.04 \\
.04 \\
.04\end{array}$ & $\begin{array}{l}.57 \\
.59 \\
.61\end{array}$ & 9.0 & 1,600 & $1,600 \mathrm{G}$ & $1,600 \mathrm{G}^{2}$ & 1.34 & Do. \\
\hline
\end{tabular}

$1,600 \mathrm{G}$ for ash fusion temperatures means greater than $1600^{\circ} \mathrm{C}$.

sulfur in coal beds of the Pocahontas Formation is determined to be organic. In comparison, younger coal beds in the New River Formation contain either mostly organic sulfur or a combination of organic and pyritic sulfur (see table 1). In general, the older coals of the Pocahontas Formation contain less total sulfur than do coal beds in the New River Formation. The low sulfate sulfur values reported in table 1 suggest that oxidation of sample splits has not been a major factor in the chemistry of these coal samples.

\section{COAL RANK VARIATIONS WITH DEPTH}

The analytical results in table 1 show that the rank of the coals increases as depth of burial increases and almost completely spans the medium-volatile bituminous coal range. Commonly there is a general increase in fixed carbon and decrease in volatile matter from the 
TABLE 2.-Arithmetic mean, observed range, geometric mean, and geometric deviation of proximate and ultimate analyses, heat of combustion, forms of sulfur, ash-fusion temperatures, free-swelling index, and real specific-gravity determinations for 12 coal samples from Virginia and West Virginia.

[All values are in percent except Btu per pound, ash-fusion temperature, free-swelling index and specific gravity. ${ }^{\circ} \mathrm{F}=9 / 5{ }^{\circ} \mathrm{C}+32 ; 1 \mathrm{kcal} / \mathrm{kg}=0.556 \mathrm{Btu} / \mathrm{lb}$; a-statistics for nine samples]

\begin{tabular}{|c|c|c|c|c|c|}
\hline \multirow{2}{*}{ Item } & \multirow{2}{*}{$\begin{array}{l}\text { Arithmetic } \\
\text { mean }\end{array}$} & \multicolumn{2}{|c|}{ Observed range } & \multirow{2}{*}{$\begin{array}{c}\text { Geometric } \\
\text { mean }\end{array}$} & \multirow{2}{*}{$\begin{array}{l}\text { Geometric } \\
\text { deviation }\end{array}$} \\
\hline & & Minimum & Maximum & & \\
\hline \multicolumn{6}{|c|}{ Proximate and ultimate analyses } \\
\hline Moisture & 2.7 & 0.9 & 6.2 & 2.42 & 1.61 \\
\hline Volatile matter & 24.0 & 20.8 & 27.8 & 23.92 & 1.10 \\
\hline Fixed carbon & 66.8 & 59.9 & 72.3 & 66.73 & 1.06 \\
\hline Ash $\ldots$ & - 6.4 & 3.6 & 11.40 & 5.96 & 1.47 \\
\hline Hydrogen & 4.8 & 4.5 & 5.10 & 4.82 & 1.04 \\
\hline Carbon & 80.9 & 70.8 & 85.30 & 80.85 & 1.05 \\
\hline Nitrogen & 1.2 & 1.0 & 1.40 & 1.24 & 1.10 \\
\hline Oxygen & 5.9 & 3.9 & 11.70 & 5.70 & 1.29 \\
\hline Total sulfur & 0.7 & 0.5 & 1.1 & 0.63 & 1.26 \\
\hline \multicolumn{6}{|c|}{ Heat of combustion } \\
\hline $\mathrm{Btu} / \mathrm{lb}$ & - 14,140 & 12,130 & 15,000 & 14,120 & 1.05 \\
\hline \multicolumn{6}{|c|}{ Forms of sulfur } \\
\hline Sulfate & .03 & .01 & 0.13 & 0.02 & 2.41 \\
\hline Pyritic & .13 & .04 & 0.43 & 0.09 & 2.14 \\
\hline Organic & .50 & .40 & 0.64 & 0.49 & 1.16 \\
\hline \multicolumn{6}{|c|}{ Ash-fusion temperatures ${ }^{\circ} \mathrm{C}$} \\
\hline Initial deformation & 1355 & 1140 & 1600 & 1345 & 1.12 \\
\hline Softening temperature ${ }^{a}$ & 1310 & 1165 & 1500 & 1310 & 1.07 \\
\hline Fluid temperature ${ }^{s}$ & 1375 & 1195 & 1530 & 1375 & 1.07 \\
\hline \multicolumn{6}{|c|}{ Free-swelling index } \\
\hline Number & 7.9 & 1.5 & 9 & 7.33 & 1.63 \\
\hline \multicolumn{6}{|c|}{ Real specific gravity } \\
\hline & 1.35 & 1.32 & 1.43 & & \\
\hline
\end{tabular}

younger to the older coal beds. The four samples of the Upper Horsepen coal bed contain significantly larger amounts of volatile matter and less fixed carbon than the three samples of the Pocahontas No. 3 coal bed, which is roughly $244 \mathrm{~m}$ (about $800 \mathrm{ft}$ ) below the Upper Horsepen coal bed (pl. 2). The five other coal samples from intervening coal beds generally follow the same trend, with one or two minor variances. Similar phenomena were noted by previous workers during studies of coal rank. However, they did not fully consider the structural settings of the sampled coals when evaluating the sample data. In this report we attempt to show that the increase in rank of the coal samples from the study area in Virginia and West Virginia results from two processes: depth of burial and structural deformation.

In figure 3 , the fixed-carbon values and the carbon-hydrogen atomic ratios are plotted against the stratigraphic distance (depth) of the sampled coals below the Upper Horsepen coal bed. The Upper Horsepen coal bed is used as the baseline at $0 \mathrm{~m}$ depth, and the four other 
sampled coal beds are plotted according to their stratigraphic distance below the Upper Horsepen. For the purpose of interpretation, the Upper Horsepen and the Pocahontas No. 3 coal beds are the upper and lower boundaries, respectively, of an imaginary 244-m-thick slab of sedimentary rock. Linear regression curves were fitted to the two sets of point data shown in figure 3 . The calculated correlation coefficients are statistically significant for the number of samples involved. An examination of the curves reveals a direct proportional relationship between the depth of a coal sample and its fixed-carbon content, on one hand, and the depth of the same coal sample and its carbon-hydrogen atomic ratio on the other. Both increase as depth of burial increases and indicate higher metamorphic grade of the older coals. This is not surprising because, as early as 1873 , Carl Hilt demonstrated that the fixed-carbon content of coal beds increases with depth of burial in some places. He concluded that the depth of burial was the principal reason for coal increasing in rank from lignite to anthracite.

There is a strong correlation of the metamorphic grade of the five sampled coal beds with their depth of burial in the 244-m-thick slab of sedimentary rock. In all probability, the major differences that we observe in these coals, like variations in fixed carbon and volatile matter, developed during loading in the sedimentary basin. The changes in rank probably continued after the basin filled and during the onset of deformation in the area. Shearing stresses were then superimposed on the initial graduated metamorphic grade(s) of the coal column during the late Paleozoic Appalachian orogeny (Wood and others, 1969, p. 85). Aberrant or anomalous fixed-carbon values for some coal beds could be the result of weathering or of localized stresses. How much the shearing stress contributed to the metamorphic grade of the coals is uncertain. The study area is underlain by lowdipping to steeply dipping beds in open-folded to tightly folded rocks of the Dry Fork anticline, the Pocahontas syncline, and along the margin of the breached Abbs Valley anticline (pl. 3). Variations in the maceral content of the coal samples might be another partial explanation for the anomalous fixed-carbon values of the coal samples.

According to recent coalification studies in Germany by Teichmüller and Teichmuller (1966), coal rank, although susceptible to subsequent change, is mainly dependent on the original depth of burial of the coal in a basin, on the length of time of loading, and on the maceral constituents that are in the coal. The most critical factor in coal metamorphism, at least for the lower ranks of coal, is the increase in temperature with depth, about $1^{\circ} \mathrm{C}$ for every $33.3 \mathrm{~m}$ or $110 \mathrm{ft}$, because of the geothermal gradient (Lee and Clark, 1966, p. 488-489). Comparable rates of change of rank with depth are demonstrated by the Teichmullers' studies (1966, p. 134-135) of borehole coal samples in Germany 


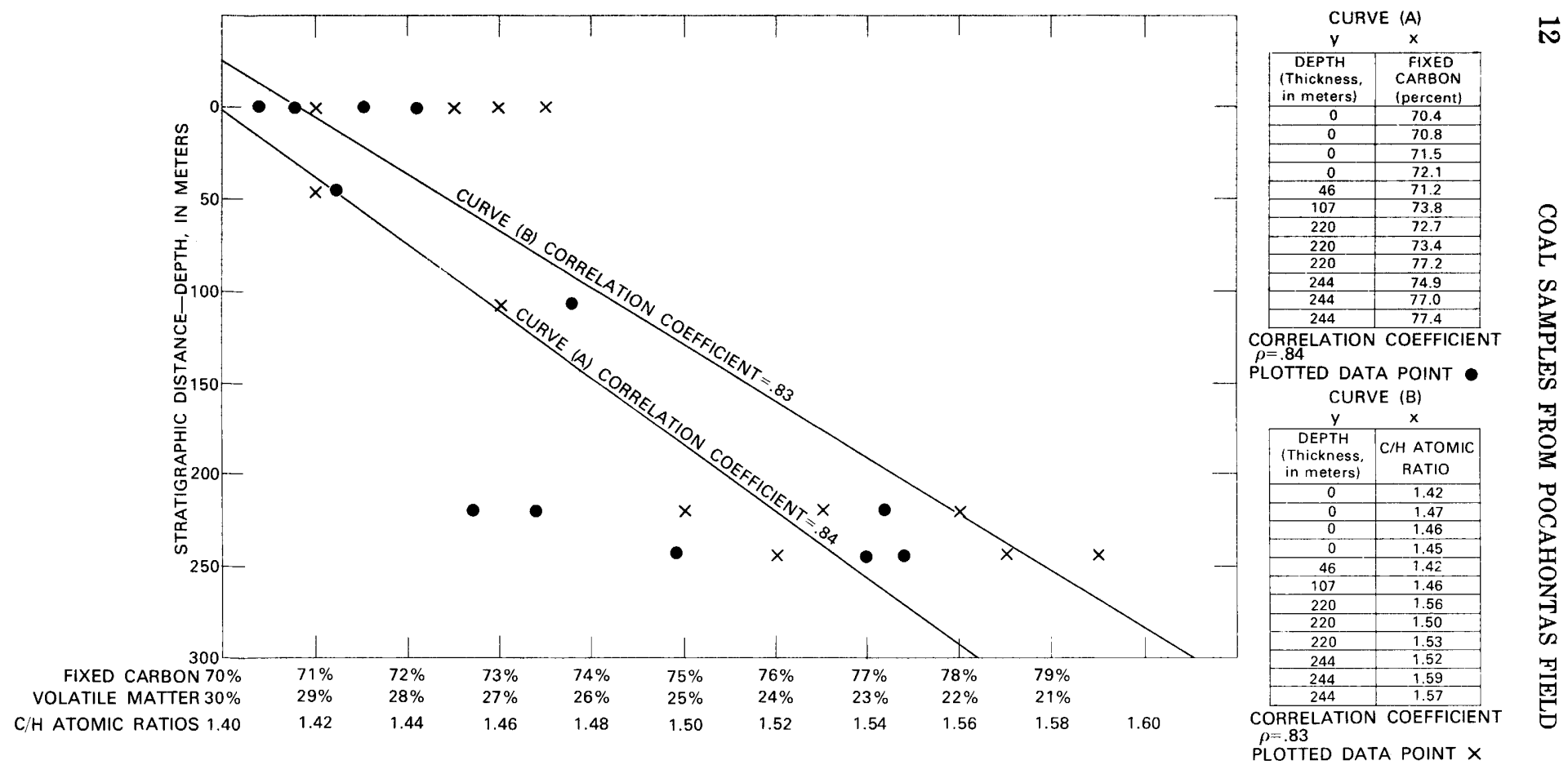

FIGURE 3.-Linear regression curves and correlation coefficients for depth (thickness) and fixed-carbon content of 12 bituminous coal samples $(A)$ and depth (thickness) and carbon-hydrogen atomic ratios of 12 bituminous coal samples $(B)$ (on a moisture- and ash-free basis). 
and the coal samples in this 800 -ft-thick section of rocks in Virginia and West Virginia. Volatile matter of the coal samples in this study area decreases from 29 to 22 percent through $244 \mathrm{~m}(800 \mathrm{ft}$ ) of section. In Germany, the borehole coal samples show a similar increase in rank by a loss of 7 percent volatile matter through $305 \mathrm{~m}(1,000 \mathrm{ft})$ of section. The rates of change of coal rank with depth in this study area and in Germany, therefore, are quite similar. Studies by the Teichmullers also suggest that increased pressure with depth of burial hinders the chemical reactions during coal metamorphism, but it does change the physical structure of the coal. Notwithstanding these observations, because the Teichmullers did not analyze their data with respect to the structure, it is conceivable that the increased fixed-carbon values could be a result of the combined effects of depth of burial (temperature) and the pressures of deformation. If the fixed-carbon values for a single coal bed are analyzed over a large area as Stadnichenko (1934) did for the Lower Kittanning coal, they are found to increase from west to east. Her study area was located in a slightly deformed and shallow part of the Appalachian Basin, which deepened eastward; therefore the shearing stress in her study area generally increased to the east also. The deformational stresses were probably superimposed on the initial (load) rank of the coal at a later time, or perhaps, in some cases, at almost the same time.

\section{U.S. GEOLOGICAL SURVEY COAL ANALYSES}

Chemical analysis of the coals for approximately 70 inorganic elements and oxides was completed using modern and highly accurate analytical methods. The 12 coal samples from Virginia and West Virginia were analyzed by the U.S. Geological Survey in two parts: on a whole-coal basis and on a laboratory-ash basis. The average abundance or arithmetic-mean values of the chemical elements and oxides were computed for the 12 coal samples. These arithmetic-mean values then were compared with baseline quantities or the arithmetic-mean values of these elements in large numbers of bituminous and Appalachian region coal samples. There are no anomalous quantities of chemical elements, based on these comparisons, in the 12 coal samples from Virginia and West Virginia.

The Geological Survey uses an ashing temperature of $525^{\circ} \mathrm{C}$ for the derivation of laboratory coal ash. If a higher ashing temperature of $750^{\circ} \mathrm{C}$ were used, as the Department of Energy does for ultimate and proximate coal analyses, several elements would be volatilized. Recommendations for trace-element analysis according to the American Society for Testing and Materials (ASTM) specifications authorize the use of a lower ashing temperature. 
U.S. GEOLOGICAL SURVEY COAL ANALYSES OF LABORATORY ASH

Major and minor oxides and the trace-element composition of the laboratory ash of the 12 coal samples are given in table 3 . The average abundances of the ash constituents shown in table 4 are compared with the arithmetic-mean values of 331 Appalachian region bituminous coal ash samples and 509 U.S. bituminous coal ash samples reported by Swanson and others (1976b, p. 55 and p. 18) (see table 5), which are considered to be baseline quantities.

No anomalous amounts of chemical elements were detected in the 12 coal-ash samples from the study area. Silica, alumina, and iron oxide are the most abundant constituents of the ashed coal samples from Virginia and West Virginia. The 12 coal samples from the study area contain roughly one-half as much ash as is contained in the baseline coal samples (see table 5). As the ash component of the coal(s) increases so do common rock-forming minerals that result in greater percentages of silica, alumina, and iron in the coal ash. Furthermore, the results in table 5 show that the mean iron $\left(\mathrm{Fe}_{2} \mathrm{O}_{3}\right)$ content in coal ash of the baseline coals is 10 and 13 percent greater than the mean iron content of the 12 coal-ash samples from the study area. Probably the main reason for the low iron values in the 12 coal samples is that no significant amount of pyrite is present in those coals. There is also a slightly higher mean quantity of trace copper in the ash of the 12 coal samples (313 parts per million), compared with the average amounts (of trace copper) in ash of 331 Appalachian region bituminous coals $(223 \mathrm{ppm})$ and 509 U.S. bituminous coals $(190 \mathrm{ppm})$ (see table 5).

A low percentage of iron and very low percentages of magnesia, soda, and potash in the coal ash suggest that the formation of scale deposits in boiler pipes and tubing during combustion or in coal conversion processes will not be a problem with these coals. The analytical results substantiate the high-quality rating which these coals have maintained through the years. There are no significant amounts of chemical elements in the ash of the 12 coal samples that detract from their value as metallurgical coals.

\section{U.S. GEOLOGICAL SURVEY GOAL ANALYSES ON A WHOLE-COAL BASIS}

Major-, minor-, and trace-element compositions of the 12 coal samples from Virginia and West Virginia are presented in table 6 on a whole-coal basis. The arithmetic means and the geometric means and deviation of the chemical elements are shown in table 7 . These average abundances of elements are then compared with baseline quantities of the elements in 331 Appalachian region coal samples and 509 bituminous coal samples in table 5. The results of this comparison indicate that no anomalous quantities of chemical elements exist in the coalchannel samples from the study area. 
Eight elements, antimony, arsenic, fluorine, mercury, lead, selenium, thorium, and uranium, could be toxic in the environment if they were in significant amounts. Only trace amounts of these elements were detected in the 12 coal samples from the study area, well within their background range in Appalachian basin coal beds. Most of the 12 coal samples from the study area contain smaller quantities of chemical elements, except strontium and barium, than the baseline coals of the Appalachian region (see table 5).

\section{PHYSICAL PROPERTIES}

Accurate and timely appraisals of the quality and quantity of U.S. coal resources will require a great deal more sampling and testing throughout the country. At present there are about three U.S. Geological Survey coal samples per billion tons of coal resources in the Eastern United States (Peter Zubovic, oral commun., December 1978). This is very sparse coal-quality data in terms of the number of detailed analyses that will soon be needed. Each physical property or chemical component of a coal that affects its ultimate use contributes to the quality of that particular coal. A property or component that is advantageous for one coal usage might be detrimental to coal quality for another; some properties and chemical elements are critical.

The common physical properties of 12 coal samples from 5 coal beds in Virginia and West Virginia were measured by the Bureau of Mines using standard coal-analysis procedures (U.S. Bureau of Mines, 1967). These analyses should provide useful data to plant designers, combustion engineers, and planners in general. Such basic data are needed to (1) examine the suitability of coal for conversion processes, (2) specify the combustion characteristics of coal, and (3) help characterize the coal more completely. Project managers may be interested either in further utilization of the coal resources of the area or in developing new coal treatment technology based upon the physical properties of the coal(s).

\section{U.S. DEPARTMENT OF ENERGY STANDARD COAL ANALYSES}

MOISTURE, ASH, AND HEAT OF COMBUSTION (HEAT VALUE)

The arithmetic mean values for the 12 coal samples in table 1 on an "as received" basis are 2.7 percent moisture, 6.4 percent ash, and 14,137 $\mathrm{Btu} / \mathrm{lb}$ heat value. These figures indicate low moisture, low ash, and good heat values for these coals. One coal sample, however, is significantly anomalous compared with the others. Coal sample,VAT-6 from the Pocahontas No. 4 coal bed has the most moisture, 6.2 percent; the most ash, 11.4 percent; and the lowest heat of combustion (calorific 
TABLE 3.-Major and minor oxide and trace-element composition of the laboratory ash of 12 coal samples from Virginia and West Virginia

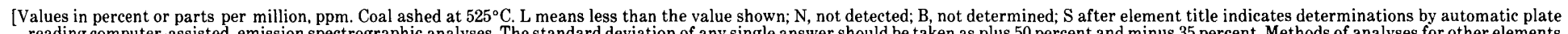
alyses for other elements shown in figures.]

\begin{tabular}{|c|c|c|c|c|c|c|c|c|c|c|c|}
\hline $\begin{array}{l}\text { Field } \\
\text { sample } \\
\text { number }\end{array}$ & $\underset{\text { (percent) }}{\text { Ash }}$ & $\underset{\text { (percent) }}{\mathrm{SiO}_{2}}$ & $\underset{\text { (percent) }}{\mathrm{Al}_{2} \mathrm{O}_{3}}$ & $\underset{\text { (percent) }}{\mathrm{CaO}}$ & $\underset{\text { (percent) }}{\mathrm{MgO}}$ & $\underset{\text { (percent) }}{\mathrm{Na}_{2} \mathrm{O}}$ & $\begin{array}{c}\mathrm{K}_{2} \mathrm{O} \\
\text { (percent) }\end{array}$ & $\underset{\text { (percent) }}{\mathrm{Fe}_{2} \mathrm{O}_{3}}$ & $\begin{array}{c}\mathrm{TiO}_{2} \\
\text { (percent) }\end{array}$ & $\underset{\text { (percent) }}{\mathrm{P}_{2} \mathrm{O}_{5}}$ & $\begin{array}{l}\text { Laboratory } \\
\text { sample } \\
\text { number }\end{array}$ \\
\hline $\begin{array}{l}\text { VAT-1 } \\
\text { JHM } 54 \\
\text { VAT-3 } \\
\text { JHM-55 } \\
\text { VAT-5 } \\
\text { JHM-56 }\end{array}$ & $\begin{array}{r}10.0 \\
-\quad 4.0 \\
-\quad 10.6 \\
8.9 \\
5.4 \\
-\quad 4.2\end{array}$ & $\begin{array}{l}39 \\
47 \\
42 \\
48 \\
40 \\
35\end{array}$ & $\begin{array}{l}26 \\
25 \\
27 \\
36 \\
27 \\
26\end{array}$ & $\begin{array}{l}2.3 \\
3.8 \\
2.0 \\
1.4 \\
2.8 \\
3.5\end{array}$ & $\begin{array}{l}1.1 \\
2.5 \\
.91 \\
1.2 \\
1.6 \\
1.6\end{array}$ & $\begin{array}{r}0.35 \\
.34 \\
.55 \\
.70 \\
.31 \\
.23\end{array}$ & $\begin{array}{c}1.2 \\
.34 \\
.94 \\
1.5 \\
1.8 \\
2.1\end{array}$ & $\begin{array}{c}9.0 \\
13 \\
3.8 \\
6.5 \\
15 \\
23\end{array}$ & $\begin{array}{c}1.3 \\
1.5 \\
1.3 \\
1.2 \\
1.1 \\
.65\end{array}$ & $\begin{array}{l}0.26 \\
.10 \mathrm{~L} \\
.31 \\
.55 \\
.04 \\
.10 \mathrm{~L}\end{array}$ & $\begin{array}{l}\text { w187040 } \\
\text { d170150 } \\
\text { w187042 } \\
\text { d170151 } \\
\text { w191521 } \\
\text { d170152 }\end{array}$ \\
\hline $\begin{array}{l}\text { VAT-6 } \\
\text { VAT-4 } \\
\text { JHM-59-- } \\
\text { VAT-2 } \\
\text { JHM-57 } \\
\text { JHM-58 }\end{array}$ & $\begin{array}{r}10.8 \\
-\quad 3.2 \\
-\quad 4.7 \\
-\quad 8.8 \\
-\quad 4.4 \\
\end{array}$ & $\begin{array}{l}52 \\
24 \\
37 \\
37 \\
46 \\
47\end{array}$ & $\begin{array}{l}23 \\
25 \\
28 \\
16 \\
27 \\
35\end{array}$ & $\begin{array}{l}1.6 \\
4.8 \\
3.6 \\
8.5 \\
6.4 \\
2.1 \\
\end{array}$ & $\begin{array}{l}.96 \\
2.0 \\
1.3 \\
2.0 \\
1.6 \\
.85\end{array}$ & $\begin{array}{c}.19 \\
.65 \\
1.5 \\
.70 \\
.52 \\
.66 \\
\end{array}$ & $\begin{array}{c}2.1 \\
1.2 \\
.52 \\
.37 \\
.36 \\
.38 \\
\end{array}$ & $\begin{array}{c}6.6 \\
13 \\
14 \\
7.9 \\
7.5 \\
5.7 \\
\end{array}$ & $\begin{array}{l}1.5 \\
1.2 \\
1.7 \\
2.0 \\
1.6 \\
1.4 \\
\end{array}$ & $\begin{array}{l}.01 \\
.09 \mathrm{~L} \\
.57 \\
.15 \\
.10 \mathrm{~L} \\
.09 \mathrm{~L} \\
\end{array}$ & $\begin{array}{l}w 191522 \\
w 187043 \\
\text { d170155 } \\
\text { w187041 } \\
\text { d170153 } \\
\text { d170154 } \\
\end{array}$ \\
\hline+2 & $\begin{array}{c}\mathrm{SO}_{3} \\
\text { (percent) }\end{array}$ & $\begin{array}{l}\mathrm{Ag}-\mathrm{S} \\
(\mathrm{ppm})\end{array}$ & $\begin{array}{c}\mathrm{B}-\mathrm{S} \\
(\mathrm{ppm})\end{array}$ & $\begin{array}{c}\mathrm{Ba-S} \\
(\mathrm{ppm})\end{array}$ & $\begin{array}{c}\mathrm{Be}-\mathrm{S} \\
(\mathrm{ppm})\end{array}$ & $\begin{array}{c}\mathrm{Cd} \\
(\mathrm{ppm})\end{array}$ & $\begin{array}{c}\mathrm{Ce} \\
(\mathrm{ppm})\end{array}$ & $\begin{array}{c}\mathrm{Co} \\
(\mathrm{ppm})\end{array}$ & $\begin{array}{c}\mathrm{Cr} \\
(\mathrm{ppm})\end{array}$ & $\begin{array}{c}\mathrm{Cs} \\
(\mathrm{ppm})\end{array}$ & \\
\hline $\begin{array}{l}\text { VAT-1 } \\
\text { JHM } 54 \\
\text { VAT-3 } \\
\text { JHM-55 } \\
\text { VAT-5 } \\
\text { JHM-56 }\end{array}$ & $\begin{array}{ll} & 0.74 \\
- & 5.5 \\
- & .50 \\
- & 1.8 \\
- & 1.4 \\
- & 4.9\end{array}$ & $\begin{array}{l}0.46 \mathrm{~L} \\
2.0 \\
.70 \\
\mathrm{~L} \\
.43 \\
2.0\end{array}$ & $\begin{array}{r}83 \\
100 \\
93 \\
70 \\
65 \\
70\end{array}$ & $\begin{array}{l}1,400 \\
7,000 \\
3,100 \\
2,000 \\
1,100 \\
2,000\end{array}$ & $\begin{array}{l}16 \\
30 \\
15 \\
7.0 \\
58 \\
20\end{array}$ & $\begin{array}{l}0.50 \mathrm{~L} \\
1.0 \mathrm{~L} \\
.50 \mathrm{~L} \\
1.0 \mathrm{~L} \\
.76 \\
1.0\end{array}$ & $\begin{array}{l}200 \\
200 \\
280 \\
300 \\
170 \\
\text { L }\end{array}$ & $\begin{array}{r}87 \\
150 \\
76 \\
70 \\
110 \\
150\end{array}$ & $\begin{array}{l}140 \\
100 \\
210 \\
100 \\
120 \\
100\end{array}$ & $\begin{array}{c}\mathrm{B} \\
\mathrm{B} \\
\mathrm{B} \\
\mathrm{B} \\
13 \\
\mathrm{~B}\end{array}$ & $\begin{array}{l}\text { w187040 } \\
\text { d170150 } \\
\text { w187042 } \\
\text { d170151 } \\
\text { w191521 } \\
\text { d170152 }\end{array}$ \\
\hline $\begin{array}{l}\text { VAT-6 } \\
\text { VAT-4 } \\
\text { JHM- } 59 \\
\text { VAT-2 } \\
\text { JHM-57 } \\
\text { JHM-58 }\end{array}$ & $\begin{array}{l}1.0 \\
2.1 \\
4.8 \\
2.0 \\
5.4 \\
2.2\end{array}$ & $\begin{array}{c}.43 \\
1.2 \\
.56 \\
.56 \\
1.0\end{array}$ & $\begin{array}{r}54 \\
100 \\
100 \\
120 \\
70 \\
100\end{array}$ & $\begin{array}{l}1,100 \\
1,800 \\
7,000 \\
1,400 \\
3,000 \\
5,000\end{array}$ & $\begin{array}{l}29 \\
20 \\
20 \\
14 \\
10 \\
20\end{array}$ & $\begin{array}{l}.52 \\
1.2 \\
1.0 \mathrm{~L} \\
.50 \mathrm{~L} \\
1.0 \mathrm{~L} \\
1.0 \mathrm{~L}\end{array}$ & $\begin{array}{l}190 \\
210 \\
300 \\
180 \\
\quad \mathrm{~L} \\
200\end{array}$ & $\begin{array}{r}46 \\
55 \\
150 \\
38 \\
70 \\
200\end{array}$ & $\begin{array}{l}120 \\
100 \\
150 \\
110 \\
150 \\
150\end{array}$ & $\begin{array}{l}13 \\
\text { B } \\
\text { B } \\
\text { B } \\
\text { B } \\
\text { B }\end{array}$ & $\begin{array}{l}\text { w191522 } \\
\text { w187043 } \\
\text { d170155 } \\
\text { w187041 } \\
\text { d170153 } \\
\text { d170154 }\end{array}$ \\
\hline & $\underset{(\mathrm{ppm})}{\mathrm{Cu}}$ & $\begin{array}{l}\text { Dy-S } \\
(\mathrm{ppm})\end{array}$ & $\begin{array}{l}\text { Er-S } \\
(\mathrm{ppm})\end{array}$ & $\begin{array}{c}\mathrm{Eu} \\
(\mathrm{ppm})\end{array}$ & $\begin{array}{l}\text { Ga-S } \\
(\mathrm{ppm})\end{array}$ & $\begin{array}{c}\mathrm{Gd}-\mathrm{S} \\
(\mathrm{ppm})\end{array}$ & $\begin{array}{c}\mathrm{Ge}-\mathrm{S} \\
(\mathrm{ppm})\end{array}$ & $\begin{array}{c}\mathrm{Hf} \\
(\mathrm{ppm})\end{array}$ & $\begin{array}{l}\mathrm{Ho}-\mathrm{S} \\
(\mathrm{ppm})\end{array}$ & $\begin{array}{c}\mathrm{La} \\
(\mathrm{ppm})\end{array}$ & 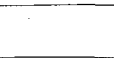 \\
\hline $\begin{array}{l}\text { VAT-1 } \\
\text { JHM-54 } \\
\text { VAT-3 } \\
\text { JHM-55 } \\
\text { VAT-5 } \\
\text { JHM-56 }\end{array}$ & $\begin{array}{l}510 \\
340 \\
140 \\
200 \\
270 \\
300\end{array}$ & $\begin{array}{l}\stackrel{7 \mathrm{~L}}{\mathrm{~N}} \\
31 \stackrel{\mathrm{N}}{58 \mathrm{~L}} \mathrm{~N}\end{array}$ & $\begin{array}{c}13 \\
16 \\
N \\
N \\
N\end{array}$ & $\begin{array}{r}2.7 \\
\mathrm{~N} \\
4.8 \\
\mathrm{~N} \\
3.3 \\
\mathrm{~N}\end{array}$ & $\begin{array}{l}42 \\
30 \\
45 \\
50 \\
31 \\
30\end{array}$ & $\begin{array}{r}15 \mathrm{~L} \\
22 \\
\mathrm{~N} \\
12 \mathrm{~L} \\
\mathrm{~N}\end{array}$ & $\begin{array}{c}9.2 \\
15 \\
4.0 \\
\mathrm{~N} \\
8.3 \mathrm{~L} \\
\mathrm{~N}\end{array}$ & $\begin{array}{r}22 \mathrm{~L} \\
\mathrm{~N} \\
22 \mathrm{~L} \\
\mathrm{~N} \\
5.6 \\
\mathrm{~N}\end{array}$ & $\begin{array}{r}4.7 \\
\mathrm{~N} \\
5.0 \\
\mathrm{~N} \\
12 \mathrm{~L} \\
\mathrm{~N}\end{array}$ & $\begin{array}{r}92 \\
150 \\
150 \\
150 \\
74 \\
100\end{array}$ & $\begin{array}{l}\text { w187040 } \\
\text { d170150 } \\
\text { w187042 } \\
\text { d170151 } \\
\text { w191521 } \\
\text { d170152 }\end{array}$ \\
\hline $\begin{array}{l}\text { VAT-6 } \\
\text { VAT-4 } \\
\text { JHM-59 } \\
\text { VAT -2 } \\
\text { JHM-57 } \\
\text { JHM-58 }\end{array}$ & $\begin{array}{r}300 \\
-\quad 230 \\
-\quad 340 \\
-\quad 690 \\
-\quad 170 \\
-\quad 270\end{array}$ & $\begin{array}{r}58 \mathrm{~L} \\
7 \mathrm{~L} \\
\mathrm{~N} \\
7 \mathrm{~L} \\
\mathrm{~N} \\
\mathrm{~N}\end{array}$ & $\begin{array}{r}18 \mathrm{~L} \\
10 \\
\mathrm{~N} \\
7.9 \\
\mathrm{~N} \\
\mathrm{~N}\end{array}$ & $\begin{array}{r}3.3 \\
3.2 \\
\mathrm{~N} \\
3.4 \\
\mathrm{~N} \\
\mathrm{~N}\end{array}$ & $\begin{array}{l}29 \\
48 \\
70 \\
31 \\
20 \\
30\end{array}$ & $\begin{array}{l}{ }_{28}^{12 \mathrm{~L}} \\
{ }_{\mathrm{N}} \\
2{ }_{\mathrm{N}} \\
\mathrm{N}\end{array}$ & $\begin{array}{l}8.3 \mathrm{~L} \\
3.2 \mathrm{~L} \\
\mathrm{~N} \\
3.2 \mathrm{~L} \\
\mathrm{~N} \\
\mathrm{~N}\end{array}$ & $\begin{array}{r}10 \\
22 \mathrm{~L} \\
\mathrm{~N} \\
22 \mathrm{~L} \\
\mathrm{~N} \\
\mathrm{~N}\end{array}$ & $\begin{array}{l}12 \mathrm{~L} \\
6.0 \\
\mathrm{~N} \\
3.2 \mathrm{~L} \\
\mathrm{~N} \\
\mathrm{~N}\end{array}$ & $\begin{array}{r}100 \\
110 \\
200 \\
95 \\
100 \\
200\end{array}$ & $\begin{array}{l}\text { w191522 } \\
\text { w187043 } \\
\text { d170155 } \\
\text { w187041 } \\
\text { d170153 } \\
\text { d170154 }\end{array}$ \\
\hline
\end{tabular}




\begin{tabular}{|c|c|c|c|c|c|c|c|c|c|c|c|}
\hline & $\underset{(\mathrm{ppm})}{\mathrm{Li}}$ & $\begin{array}{c}\mathrm{Lu} \\
(\mathrm{ppm})\end{array}$ & $\underset{(\mathrm{ppm})}{\mathrm{Mn}}$ & $\begin{array}{c}\text { Mo-S } \\
(\mathrm{ppm})\end{array}$ & $\begin{array}{l}\mathrm{Nb}-\mathrm{S} \\
(\mathrm{ppm})\end{array}$ & $\begin{array}{l}\mathrm{Nd}-\mathrm{S} \\
(\mathrm{ppm})\end{array}$ & $\begin{array}{c}\mathrm{Ni-S} \\
(\mathrm{ppm})\end{array}$ & $\begin{array}{c}\mathrm{Pb} \\
(\mathrm{ppm})\end{array}$ & $\begin{array}{c}\mathrm{Pr}-\mathrm{S} \\
(\mathrm{ppm})\end{array}$ & $\begin{array}{c}\mathrm{Rb} \\
(\mathrm{ppm})\end{array}$ & \\
\hline $\begin{array}{l}\text { VAT-1 } \\
\text { JHM-54 } \\
\text { VAT-3 } \\
\text { JHM-55 } \\
\text { VAT-5 } \\
\text { JHM-56 }\end{array}$ & $\begin{array}{l}260 \\
180 \\
250 \\
290 \\
130 \\
220\end{array}$ & $\begin{array}{l}3 \mathrm{~L} \\
\mathrm{~N} \\
3 \mathrm{~L} \\
\mathrm{~N} \\
2 \mathrm{~N}\end{array}$ & $\begin{array}{l}210 \\
150 \\
150 \\
300 \\
120 \\
200\end{array}$ & $\begin{array}{l}15 \\
15 \\
15 \\
15 \\
36 \\
50\end{array}$ & $\begin{array}{l}11 \\
20 \\
29 \\
15 \\
10 \\
{ }_{\mathrm{L}}\end{array}$ & $\begin{array}{c}68 \mathrm{~L} \\
\mathrm{~L} \\
68 \mathrm{~L} \\
150 \\
120 \\
\mathrm{~L}\end{array}$ & $\begin{array}{l}100 \\
200 \\
140 \\
100 \\
120 \\
150\end{array}$ & $\begin{array}{r}100 \\
55 \\
93 \\
55 \\
48 \\
65\end{array}$ & $\begin{array}{l}15 \\
\mathrm{~N} \\
22 \\
\mathrm{~N} \\
120 \mathrm{~L} \\
\mathrm{~N}\end{array}$ & $\begin{array}{r}\mathrm{B} \\
\mathrm{B} \\
\mathrm{B} \\
\mathrm{B} \\
130 \\
{ }_{\mathrm{B}}\end{array}$ & $\begin{array}{l}\text { w187040 } \\
\text { d170150 } \\
\text { w187042 } \\
\text { d170151 } \\
\text { w191521 } \\
\text { d170152 }\end{array}$ \\
\hline $\begin{array}{l}\text { VAT-6 } \\
\text { VAT-4 } \\
\text { JHM-59 } \\
\text { VAT-2 } \\
\text { JHM-57--- } \\
\text { JHM-58 }\end{array}$ & $\begin{array}{l}120 \\
170 \\
170 \\
120 \\
280 \\
260\end{array}$ & $\begin{array}{r}.9 \\
3 \mathrm{~L} \\
\mathrm{~N} \\
3 \mathrm{~L} \\
\mathrm{~N}\end{array}$ & $\begin{array}{r}110 \\
830 \\
700 \\
180 \\
300 \\
70\end{array}$ & $\begin{array}{l}16 \\
52 \\
50 \\
14 \\
10 \\
30\end{array}$ & $\begin{array}{l}17 \\
14 \\
30 \\
17 \\
20 \\
15\end{array}$ & $\begin{array}{c}83 \mathrm{~L} \\
68 \mathrm{~L} \\
150 \\
68 \mathrm{~L} \\
\mathrm{~N} \\
100\end{array}$ & $\begin{array}{r}74 \\
170 \\
150 \\
120 \\
100 \\
200\end{array}$ & $\begin{array}{r}58 \\
76 \\
100 \\
96 \\
65 \\
80\end{array}$ & $\begin{array}{c}120 \mathrm{~L} \\
18 \\
15 \\
\mathrm{~N} \\
\mathrm{~N}\end{array}$ & $\begin{array}{l}140 \\
\mathrm{~B} \\
\mathrm{~B} \\
\mathrm{~B} \\
\mathrm{~B} \\
\mathrm{~B}\end{array}$ & $\begin{array}{l}\text { w191522 } \\
\text { w187043 } \\
\text { d170155 } \\
\text { w187041 } \\
\text { d170153 } \\
\text { d170154 }\end{array}$ \\
\hline & $\begin{array}{c}\mathrm{Sc} \\
(\mathrm{ppm})\end{array}$ & $\begin{array}{c}\mathrm{Sm} \\
(\mathrm{ppm})\end{array}$ & $\begin{array}{c}\mathrm{Sn}-\mathrm{S} \\
(\mathrm{ppm})\end{array}$ & $\begin{array}{c}\mathrm{Sr}-\mathrm{S} \\
(\mathrm{ppm})\end{array}$ & $\begin{array}{c}\mathrm{Tb} \\
(\mathrm{ppm})\end{array}$ & $\begin{array}{c}\text { Th } \\
\text { (ppm) }\end{array}$ & $\begin{array}{c}\mathrm{U} \\
(\mathrm{ppm})\end{array}$ & $\begin{array}{c}\mathrm{V}-\mathrm{S} \\
(\mathrm{ppm})\end{array}$ & $\begin{array}{c}\mathrm{Y}-\mathrm{S} \\
(\mathrm{ppm})\end{array}$ & $\begin{array}{c}\mathrm{Yb} \\
(\mathrm{ppm})\end{array}$ & \\
\hline $\begin{array}{l}\text { VAT-1 } \\
\text { JHM-54 } \\
\text { VAT-3 } \\
\text { JHM-55 } \\
\text { VAT-5 } \\
\text { JHM-56 }\end{array}$ & $\begin{array}{l}29 \\
30 \\
39 \\
30 \\
24 \\
50\end{array}$ & $\begin{array}{l}19 \\
1{ }^{12} \mathrm{~N} \\
\mathrm{~N}\end{array}$ & $\begin{array}{r}15 \mathrm{~L} \\
\mathrm{~N} \\
15 \mathrm{~L} \\
\mathrm{~N} \\
12 \mathrm{~L} \\
\mathrm{~N}\end{array}$ & $\begin{array}{l}1,800 \\
5,000 \\
2,400 \\
1,500 \\
2,500 \\
3,000\end{array}$ & $\begin{array}{r}10 \mathrm{~L} \\
\mathrm{~N} \\
10 \mathrm{~L} \\
\mathrm{~N} \\
3.7 \\
\mathrm{~N}\end{array}$ & $\begin{array}{l}{ }^{40} \mathrm{~B} \\
47 \\
36 \\
56 \mathrm{~L} \\
\mathrm{~B}\end{array}$ & $\begin{array}{l}13 \\
14 \\
12 \\
10 \\
19 \\
40\end{array}$ & $\begin{array}{l}180 \\
150 \\
300 \\
300 \\
160 \\
300\end{array}$ & $\begin{array}{r}73 \\
150 \\
90 \\
100 \\
96 \\
150\end{array}$ & $\begin{array}{c}6.6 \\
10 \\
8.1 \\
10 \\
9.3 \\
10\end{array}$ & $\begin{array}{l}\text { w187040 } \\
\text { d170150 } \\
\text { w187042 } \\
\text { d170151 } \\
\text { w191521 } \\
\text { d170152 }\end{array}$ \\
\hline $\begin{array}{l}\text { VAT-6 } \\
\text { VAT-4 } \\
\text { JHM-59- } \\
\text { VAT-2 } \\
\text { JHM -57 } \\
\text { JHM- } 58\end{array}$ & $\begin{array}{l}24 \\
26 \\
50 \\
23 \\
50 \\
50\end{array}$ & $\begin{array}{l}18 \\
13 \\
\mathrm{~N} \\
12^{\mathrm{N}} \\
\mathrm{N}\end{array}$ & $\begin{array}{l}12 \mathrm{~L} \\
15 \mathrm{~L} \\
\mathrm{~N} \\
3{ }^{\mathrm{N}} \\
10\end{array}$ & $\begin{array}{l}1,400 \\
2,900 \\
3,000 \\
2,400 \\
2,000 \\
3,000\end{array}$ & $\begin{array}{r}2.8 \\
10 \mathrm{~L} \\
\mathrm{~N} \\
10 \mathrm{~L} \\
\mathrm{~N} \\
\mathrm{~N}\end{array}$ & $\begin{array}{c}28 \mathrm{~L} \\
94 \mathrm{~L} \\
110 \\
59 \\
40 \\
76\end{array}$ & $\begin{array}{l}15 \\
19 \\
16 \\
10 \\
14 \\
14\end{array}$ & $\begin{array}{l}160 \\
200 \\
300 \\
140 \\
150 \\
300\end{array}$ & $\begin{array}{r}60 \\
86 \\
200 \\
79 \\
100 \\
150\end{array}$ & $\begin{array}{c}8.3 \\
6.4 \\
15 \\
6.5 \\
10 \\
15\end{array}$ & $\begin{array}{l}\text { w191522 } \\
\text { w187043 } \\
\text { d170155 } \\
\text { w187041 } \\
\text { d170153 } \\
\text { d170154 }\end{array}$ \\
\hline & $\begin{array}{c}\mathrm{Zn} \\
(\mathrm{ppm})\end{array}$ & $\begin{array}{l}\mathrm{Zr}-\mathrm{S} \\
(\mathrm{ppm})\end{array}$ & & & & & & & & & \\
\hline $\begin{array}{l}\text { VAT-1 } \\
\text { JHM-54 } \\
\text { VAT-3 } \\
\text { JHM-55 } \\
\text { VAT-5 } \\
\text { JHM-56 }\end{array}$ & $\begin{array}{r}86 \\
110 \\
42 \\
39 \\
35 \\
220\end{array}$ & $\begin{array}{l}320 \\
300 \\
530 \\
200 \\
160 \\
100\end{array}$ & & & & & & & & & $\begin{array}{l}\text { w187040 } \\
\text { w170150 } \\
\text { w187042 } \\
\text { d170151 } \\
\text { w191521 } \\
\text { d170152 }\end{array}$ \\
\hline $\begin{array}{l}\text { VAT-6 } \\
\text { VAT-4 } \\
\text { JHM-59 } \\
\text { VAT-2 } \\
\text { JHM-57--- } \\
\text { JHM-58 }\end{array}$ & $\begin{array}{r}57 \\
100 \\
150 \\
86 \\
34 \\
40\end{array}$ & $\begin{array}{l}160 \\
340 \\
300 \\
380 \\
300 \\
300\end{array}$ & & & & & & & . & & $\begin{array}{l}\text { w191522 } \\
\text { w187043 } \\
\text { d170155 } \\
\text { w187041 } \\
\text { d170153 } \\
\text { d170154 }\end{array}$ \\
\hline
\end{tabular}


TABLE 4.-Arithmetic mean, observed range, geometric mean, and geometric deviation of ash content and contents of 11 major and minor oxides in the laboratory ash of 12 coal samples from Virginia and West Virginia

[All samples were ashed at $525^{\circ} \mathrm{C}$; all analyses except geometric deviation are in percent]

\begin{tabular}{|c|c|c|c|c|c|}
\hline \multirow{2}{*}{ Oxide } & \multirow{2}{*}{$\begin{array}{l}\text { Arithmetic } \\
\text { mean }\end{array}$} & \multicolumn{2}{|c|}{ Observed range } & \multirow{2}{*}{$\begin{array}{c}\text { Geometric } \\
\text { mean }\end{array}$} & \multirow{2}{*}{$\begin{array}{l}\text { Geometric } \\
\text { deviation }\end{array}$} \\
\hline & & Minimum & Maximum & & \\
\hline Ash & $\ldots 6.8$ & 3.2 & 10.8 & 6.27 & 1.52 \\
\hline $\mathrm{SiO}_{2,--}$ & 41.2 & 24.0 & 52.0 & 40.44 & 1.22 \\
\hline $\mathrm{Al}_{2} \mathrm{O}_{3--}$ & 26.8 & 16.00 & 36.00 & 26.27 & 1.22 \\
\hline $\mathrm{CaO}_{\ldots}$ & $\ldots 3.57$ & 1.40 & 8.50 & 3.09 & 1.69 \\
\hline $\mathrm{MgO}_{\ldots}$ & _... 1.47 & .85 & 2.50 & 1.38 & 1.39 \\
\hline $\mathrm{Na}_{2} \mathrm{O}_{-}$ & $\begin{array}{ll}- & .56\end{array}$ & .19 & 1.51 & .48 & 1.73 \\
\hline $\mathrm{K}_{2} \mathrm{O}_{\ldots}$ & --- 1.07 & .34 & 2.10 & .85 & 2.02 \\
\hline $\mathrm{Fe}_{2} \mathrm{O}_{3}$ & $\ldots 10.4$ & 3.80 & 23.00 & 9.27 & 1.62 \\
\hline $\mathrm{TiO}_{2}$ & _-- 1.4 & .65 & 2.00 & 1.33 & 1.31 \\
\hline $\mathrm{P}_{2} \mathrm{O}_{5}$ & -- .18 & .01 & .57 & .14 & 4.15 \\
\hline $\mathrm{SO}_{33}$ & -2.7 & .50 & 5.50 & 2.07 & 2.16 \\
\hline
\end{tabular}

TABLE 5.-Average abundance of chemical elements and oxides in 12 whole coal and ash samples from Virginia and West Virginia compared with 331 Appalachian region and 509 bituminous coal samples

\begin{tabular}{|c|c|c|c|}
\hline \multicolumn{4}{|c|}{ Whole coal } \\
\hline \multirow[b]{2}{*}{ Element } & & means & \\
\hline & This study ${ }^{\mathrm{l}}$ & $\begin{array}{l}\text { 331 Appalachian } \\
\text { coal samples }\end{array}$ & $\begin{array}{l}509 \text { bituminous } \\
\text { coal samples: }\end{array}$ \\
\hline \multicolumn{4}{|c|}{ Percent } \\
\hline -...... & 1.36 & 2.7 & 2.6 \\
\hline $\mathrm{Al}_{-\ldots}$ & .96 & 1.6 & 1.4 \\
\hline $\mathrm{Ca}_{-}$ & .16 & .12 & .33 \\
\hline $\mathrm{Mg}$ & .055 & .068 & .08 \\
\hline $\mathrm{Na}$ & .027 & .032 & .04 \\
\hline $\mathrm{K}_{\ldots} \ldots$ & .06 & .23 & .21 \\
\hline $\mathrm{Fe}_{-}$ & .43 & 1.9 & 2.2 \\
\hline $\mathrm{Ti}$ & .06 & .09 & .08 \\
\hline \multicolumn{4}{|c|}{ Parts per milliom } \\
\hline $\mathrm{Mn}_{-}$ & 16.6 & 620 & 100 \\
\hline $\mathrm{As}_{\ldots} \ldots$ & 8.9 & 27 & 25 \\
\hline $\mathrm{Cd}_{-}$ & .03 & .7 & 1.6 \\
\hline $\mathrm{Cu}_{-}$ & 21.3 & 24 & 22 \\
\hline - & 39 & 80 & 77 \\
\hline $\mathrm{Hg}$ & .07 & .24 & .20 \\
\hline $\mathrm{Li}$ & 14.4 & 27.6 & 23 \\
\hline $\mathrm{Pb}_{-}$ & 5.1 & 15.3 & 22 \\
\hline $\mathrm{Sb}$ & .72 & 1.2 & 1.4 \\
\hline $\mathrm{Se}_{\ldots}$ & 1.8 & 4.7 & 4.6 \\
\hline Th & 3.28 & 4.9 & 5.0 \\
\hline $\mathrm{U}_{-}$ & 1.03 & 1.4 & 1.9 \\
\hline $\mathrm{Zn}$ & 4.9 & 20.0 & 53 \\
\hline$B_{2}$ & 5.6 & 30 & 50 \\
\hline
\end{tabular}

"Arithmetic mean calculated using tabulated results, one-half the "less than" values (L).

4 Swanson and others, 1976, p. 56.

- 1976, p. 19 
TABLE 5.-Average abundance of chemical elements and oxides in 12 whole coal and ash samples from Virginia and West Virginia compared with 331 Appalachian region and 509 bituminous coal samples-Continued

\begin{tabular}{|c|c|c|c|}
\hline \multicolumn{4}{|c|}{ Whole coal } \\
\hline \multicolumn{4}{|c|}{ Arithmetic means } \\
\hline Element & This study' ${ }^{\prime}$ & $\begin{array}{c}\text { 331 Appalachian } \\
\text { coal samples }^{2}\end{array}$ & $\begin{array}{c}509 \text { bituminous } \\
\text { coal samples: }\end{array}$ \\
\hline \multicolumn{4}{|c|}{ Parts per million } \\
\hline ..........- & -180.8 & 100 & 100 \\
\hline $\mathrm{Be}$ & 1.35 & 2 & 2 \\
\hline $\mathrm{Co} \ldots$ & 6.0 & 7 & 7 \\
\hline $\mathrm{Cr}$ & 9.4 & 20 & 15 \\
\hline - & 2.6 & 7 & 7 \\
\hline - & 1.5 & 3 & 3 \\
\hline $\mathrm{Nb}$ & 1.3 & 5 & 3 \\
\hline $\mathrm{Ni}$ & 8.4 & 15 & 20 \\
\hline $\mathrm{Sc}_{\ldots} \ldots$ & 2.4 & 5 & 3 \\
\hline (n) & 156.9 & 100 & 100 \\
\hline$V_{\ldots}$ & 14.7 & 20 & 20 \\
\hline$Y_{-}$ & 6.9 & 10 & 10 \\
\hline$Y b_{-}$ & .6 & 1 & 1 \\
\hline $\mathrm{Zr}$ & 19.9 & 50 & 30 \\
\hline \multicolumn{4}{|c|}{ Coal ash ${ }^{4}$} \\
\hline \multicolumn{4}{|c|}{ Arithmetic means } \\
\hline $\begin{array}{c}\text { Oxide } \\
\text { or } \\
\text { element }\end{array}$ & This study ${ }^{1}$ & $\begin{array}{l}\text { 331 Appalachian } \\
\text { coal samples }\end{array}$ & $\begin{array}{l}509 \text { bituminous } \\
\text { coal samples }\end{array}$ \\
\hline \multicolumn{4}{|c|}{ Percent } \\
\hline Ash & 6.8 & 13.3 & 13.9 \\
\hline $\mathrm{SiO}_{2}$ & 41.2 & 41.0 & 38 \\
\hline $\mathrm{Al}_{2} \mathrm{O}_{3}$ & 26.8 & 23 & 20 \\
\hline $\mathrm{CaO}$ & 3.57 & 1.9 & 4.3 \\
\hline $\mathrm{MgO}$ & 1.47 & .90 & 1.1 \\
\hline $\mathrm{Na}_{2} \mathrm{O}$ & .56 & .36 & .45 \\
\hline $\mathrm{K}_{2} \mathrm{O}$ & 1.07 & 1.80 & 1.6 \\
\hline $\mathrm{Fe}_{2} \mathrm{O}_{3}$ & 10.4 & 21 & 23 \\
\hline $\mathrm{MnO}$ & .02 & .073 & .10 \\
\hline $\mathrm{TiO}_{2-1}$ & 1.4 & 1.2 & 1.0 \\
\hline $\mathrm{SO}_{3-1}$ & 2.70 & 2.4 & 3.9 \\
\hline \multicolumn{4}{|c|}{ Parts per million } \\
\hline $\mathrm{Cd}_{-}$ & 0.56 & 5.4 & 12.3 \\
\hline $\mathrm{Cu}$ & 313 & 223 & 190 \\
\hline $\mathrm{Li}_{-}$ & 204 & 197 & 167 \\
\hline $\mathrm{Pb}_{\ldots}$ & 74.3 & 116 & 151 \\
\hline $\mathrm{Zn}$ & 83.3 & 156 & 368 \\
\hline
\end{tabular}

'All coal samples ashed at $525^{\circ} \mathrm{C}$.

Swanson and others, 1976, p. 55.

i. 1976 , p. 18

value), $12,130 \mathrm{Btu} / \mathrm{lb}$. On the other hand, sample VAT-6 has the highest specific gravity, 1.43 , and a very low free-swelling index number, 1.5. These data suggest that either the Pocahontas No. 4 coal bed at this sample locality is not of coking quality or the coal sample may be weathered (oxidized). A low free-swelling index, low heat value, and 
TABLE 6.-Major-, minor-, and trace-element composition of 12 coal samples from Virginia and West Virginia on a whole-coal basis

[Values in percent or parts per million; 22 values are from direct determinations on whole coal; all other values calculated from analyses of ash. $\mathrm{S}$ means analysis by emission spectrography; $\mathrm{L}$, less than

value shown; $N$, not detected; $B$, not determined.]

\begin{tabular}{|c|c|c|c|c|c|c|c|c|c|c|c|}
\hline $\begin{array}{l}\text { Field } \\
\text { sample } \\
\text { number }\end{array}$ & $\begin{array}{c}\mathrm{Si} \\
\text { (percent) }\end{array}$ & $\begin{array}{c}\mathrm{Al} \\
\text { (percent) }\end{array}$ & $\begin{array}{c}\mathrm{Ca} \\
\text { (percent) }\end{array}$ & $\begin{array}{c}\mathrm{Mg} \\
\text { (percent) }\end{array}$ & $\begin{array}{c}\mathrm{Na} \\
\text { (percent) }\end{array}$ & $\begin{array}{c}\mathrm{K} \\
\text { (percent) }\end{array}$ & $\begin{array}{c}\mathrm{Fe} \\
\text { (percent) }\end{array}$ & $\begin{array}{c}\mathrm{Ti} \\
\text { (percent) }\end{array}$ & $\begin{array}{c}\mathrm{Ag-S} \\
(\mathrm{ppm})\end{array}$ & $\underset{(\mathrm{ppm})}{\mathrm{As}}$ & $\begin{array}{c}\text { Laboratory } \\
\text { sample } \\
\text { number }\end{array}$ \\
\hline 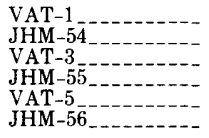 & $\begin{array}{l}1.8 \\
.88 \\
2.1 \\
2.0 \\
1.0 \\
.69\end{array}$ & $\begin{array}{l}1.4 \\
.53 \\
1.5 \\
1.7 \\
.77 \\
.58\end{array}$ & $\begin{array}{l}0.16 \\
.11 \\
.15 \\
.089 \\
.11 \\
.10\end{array}$ & $\begin{array}{r}0.065 \\
.060 \\
.058 \\
.063 \\
.051 \\
.040\end{array}$ & $\begin{array}{l}0.026 \\
.010 \\
.043 \\
.046 \\
.012 \\
.007\end{array}$ & $\begin{array}{l}0.083 \\
.033 \\
.088 \\
.074 \\
.045 \\
.035\end{array}$ & $\begin{array}{r}0.63 \\
.36 \\
.28 \\
.40 \\
.57 \\
.68\end{array}$ & $\begin{array}{r}0.078 \\
.036 \\
.083 \\
.064 \\
.036 \\
.016\end{array}$ & $\begin{array}{l}0.05 \mathrm{~L} \\
.08 \\
.07 \\
\mathrm{~L} \\
.02 \\
.08\end{array}$ & $\begin{array}{c}11 \\
2.0 \\
4.9 \\
4.0 \\
11 \\
12\end{array}$ & $\begin{array}{l}\text { w187040 } \\
\text { d170150 } \\
\text { w187042 } \\
\text { d } 170151 \\
\text { w191521 } \\
\text { d170152 }\end{array}$ \\
\hline $\begin{array}{l}\text { VAT-6 } \\
\text { VAT-4 } \\
\text { JHM-59.-1.- } \\
\text { VAT-2 } \\
\text { JHM-57 } \\
\text { JHM-58 }\end{array}$ & $\begin{array}{c}2.6 \\
.36 \\
.81 \\
1.2 \\
1.9 \\
.97\end{array}$ & $\begin{array}{c}1.3 \\
.42 \\
.70 \\
.58 \\
1.3 \\
.81\end{array}$ & $\begin{array}{l}.12 \\
.11 \\
.41 \\
.41 \\
.066\end{array}$ & $\begin{array}{l}.062 \\
.038 \\
.036 \\
.081 \\
.085 \\
.023\end{array}$ & $\begin{array}{l}.015 \\
.015 \\
.053 \\
.035 \\
.034 \\
.022\end{array}$ & $\begin{array}{l}.090 \\
.027 \\
.039 \\
.057 \\
.074 \\
.037 \\
\end{array}$ & $\begin{array}{l}.50 \\
.29 \\
.46 \\
.38 \\
.47 \\
.18\end{array}$ & $\begin{array}{l}.097 \\
.023 \\
.048 \\
.081 \\
.085 \\
.037\end{array}$ & $\begin{array}{l}.05 \\
.04 \\
\mathrm{~L} \\
.04 \\
\mathrm{~L} \\
.04 \\
\end{array}$ & $\begin{array}{l}39 \\
6.0 \\
5.0 \\
3.3 \\
5.0 \\
3.0\end{array}$ & $\begin{array}{l}\text { w191522 } \\
\text { w187043 } \\
\text { d170155 } \\
\text { w187041 } \\
\text { d170153 } \\
\text { d170154 }\end{array}$ \\
\hline & $\begin{array}{c}\text { B-S } \\
(\mathrm{ppm})\end{array}$ & $\begin{array}{c}\mathrm{Ba}-\mathrm{S} \\
(\mathrm{ppm})\end{array}$ & $\begin{array}{c}\mathrm{Be}-\mathrm{S} \\
(\mathrm{ppm})\end{array}$ & $\begin{array}{c}\mathrm{Cd} \\
(\mathrm{ppm})\end{array}$ & $\begin{array}{c}\mathrm{Ce} \\
(\mathrm{ppm})\end{array}$ & $\begin{array}{c}\mathrm{Co} \\
(\mathrm{ppm})\end{array}$ & $\begin{array}{c}\mathrm{Cr} \\
(\mathrm{ppm})\end{array}$ & $\begin{array}{c}\mathrm{Cs} \\
(\mathrm{ppm})\end{array}$ & $\begin{array}{c}\mathrm{Cu} \\
(\mathrm{ppm})\end{array}$ & $\begin{array}{c}\text { Dy-S } \\
(\mathrm{ppm})\end{array}$ & \\
\hline 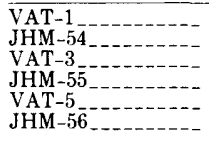 & $\begin{array}{r}8.3 \\
-\quad 9.0 \\
-\quad 6.2 \\
-\quad 3.5 \\
2.9\end{array}$ & $\begin{array}{r}140 \\
280 \\
330 \\
180 \\
59 \\
84\end{array}$ & $\begin{array}{r}1.6 \\
1.2 \\
1.6 \\
.6 \\
3.1 \\
.8\end{array}$ & $\begin{array}{l}0.05 \mathrm{~L} \\
.04 \mathrm{~L} \\
.05 \mathrm{~L} \\
.09 \mathrm{~L} \\
.04 \\
.04\end{array}$ & $\begin{array}{l}20 \\
8.0 \\
30 \\
27 \\
9.0 \\
\mathrm{~L}\end{array}$ & $\begin{array}{l}8.7 \\
6.0 \\
8.0 \\
6.2 \\
5.8 \\
6.3\end{array}$ & $\begin{array}{c}15 \\
4.0 \\
23 \\
8.9 \\
6.4 \\
4.2\end{array}$ & $\begin{array}{l}\mathrm{B} \\
\mathrm{B} \\
\mathrm{B} \\
\mathrm{B} \\
.7 \\
\mathrm{~B}\end{array}$ & $\begin{array}{l}51 \\
14 \\
15 \\
18 \\
15 \\
13\end{array}$ & $\begin{array}{l}0.7 \mathrm{~L} \\
\mathrm{~N} \\
3.3 \\
\mathrm{~N} \\
3.1 \mathrm{~L} \\
\mathrm{~N}\end{array}$ & $\begin{array}{r}\text { w187040 } \\
\text { d170150 } \\
\text { w187042 } \\
\text { d170151 } \\
\text { w191521 } \\
\text { d170152 }\end{array}$ \\
\hline 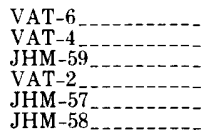 & $\begin{array}{l}5.8 \\
3.4 \\
4.7 \\
8.0 \\
6.2 \\
4.4\end{array}$ & $\begin{array}{r}120 \\
58 \\
330 \\
98 \\
270 \\
220\end{array}$ & $\begin{array}{r}3.1 \\
.6 \\
.9 \\
.9 \\
.9 \\
.9\end{array}$ & $\begin{array}{l}.06 \\
.04 \\
.05 \mathrm{~L} \\
.03 \mathrm{~L} \\
.09 \mathrm{~L} \\
.04 \mathrm{~L}\end{array}$ & $\begin{array}{l}20 \\
6.8 \\
14 \\
13 \\
\mathrm{~L} \\
8.8\end{array}$ & $\begin{array}{l}5.0 \\
1.8 \\
7.1 \\
2.6 \\
6.2 \\
8.8\end{array}$ & $\begin{array}{c}13 \\
3.3 \\
7.1 \\
7.7 \\
13 \\
6.6\end{array}$ & $\begin{array}{r}1.4 \\
\mathrm{~B} \\
\mathrm{~B} \\
\mathrm{~B} \\
\mathrm{~B} \\
\mathrm{~B}\end{array}$ & $\begin{array}{l}32 \\
7.3 \\
16 \\
47 \\
15 \\
12\end{array}$ & $\begin{array}{l}6.3 \mathrm{~L} \\
.2 \mathrm{~L} \\
\mathrm{~N} \\
.5 \mathrm{~L} \\
\mathrm{~N} \\
\mathrm{~N}\end{array}$ & $\begin{array}{l}\text { w191522 } \\
\text { w187043 } \\
\text { d170155 } \\
\text { w187041 } \\
\text { d170153 } \\
\text { d170154 }\end{array}$ \\
\hline & $\begin{array}{c}\text { Er-S } \\
(\mathrm{ppm})\end{array}$ & $\underset{(\mathrm{ppm})}{\mathrm{Eu}}$ & $\begin{array}{c}F \\
(\mathrm{ppm})\end{array}$ & $\begin{array}{c}\text { Ga-S } \\
(\mathrm{ppm})\end{array}$ & $\begin{array}{c}\text { Gd-S } \\
(\mathrm{ppm})\end{array}$ & $\begin{array}{r}\text { Ge-S } \\
(\mathrm{ppm})\end{array}$ & $\underset{(\mathrm{ppm})}{\mathrm{Hf}}$ & $\underset{(\mathrm{ppm})}{\mathrm{Hg}}$ & $\begin{array}{c}\text { Ho-S } \\
(\mathrm{ppm})\end{array}$ & $\begin{array}{c}\mathrm{La} \\
(\mathrm{ppm})\end{array}$ & \\
\hline 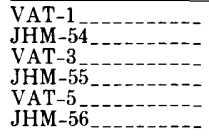 & $\begin{array}{c}1.3 \\
\mathrm{~N} \\
1.7 \\
\mathrm{~N} \\
1.0 \mathrm{~L} \\
\mathrm{~N}\end{array}$ & $\begin{array}{l}0.27 \\
\mathrm{~N} \\
.51 \\
\mathrm{~N} \\
.18 \\
\mathrm{~N}\end{array}$ & $\begin{array}{l}87 \\
20 \\
92 \\
50 \\
92 \\
20\end{array}$ & $\begin{array}{l}4.2 \\
1.2 \\
4.8 \\
4.5 \\
1.7 \\
1.3\end{array}$ & $\begin{array}{l}1.5 \mathrm{~L} \\
\mathrm{~N} \\
2.3 \\
\mathrm{~N} \\
.65 \mathrm{~L} \\
\mathrm{~N}\end{array}$ & $\begin{array}{l}0.92 \\
.60 \\
.42 \\
\mathrm{~N} \\
.45 \mathrm{~L} \\
\mathrm{~N}\end{array}$ & $\begin{array}{l}2.2 \mathrm{~L} \\
\mathrm{~N} \\
2.3 \mathrm{~L} \\
\mathrm{~N} \\
.3 \\
\mathrm{~N}\end{array}$ & $\begin{array}{l}0.050 \\
.060 \\
.080 \\
.060 \\
.060 \\
.18\end{array}$ & $\begin{array}{l}0.47 \\
\mathrm{~N} \\
.53 \\
\mathrm{~N} \\
.65 \mathrm{~L} \\
\mathrm{~N}\end{array}$ & $\begin{array}{r}9 \\
6 \\
16 \\
13 \\
4 \\
4\end{array}$ & $\begin{array}{l}\text { w187040 } \\
\text { d170150 } \\
\text { w187042 } \\
\text { d170151 } \\
\text { w191521 } \\
\text { d170152 }\end{array}$ \\
\hline 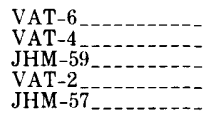 & $\begin{array}{l}1.9 \mathrm{~L} \\
.3 \\
\mathrm{~N} \\
.5 \\
\mathrm{~N}\end{array}$ & $\begin{array}{l}.36 \\
.10 \\
\mathrm{~N} \\
.23 \\
\mathrm{~N}\end{array}$ & $\begin{array}{l}28 \\
33 \\
20 \mathrm{~L} \\
20 \mathrm{~L} \\
20 \mathrm{~L}\end{array}$ & $\begin{array}{l}3.1 \\
1.5 \\
3.3 \\
2.1 \\
1.8\end{array}$ & $\begin{array}{c}1.3 \mathrm{~L} \\
.90 \\
\mathrm{~N} \\
1.5 \\
\mathrm{~N}\end{array}$ & $\begin{array}{l}.90 \mathrm{~L} \\
.10 \mathrm{~L} \\
\mathrm{~N} \\
.21 \mathrm{~L} \\
\mathrm{~N}\end{array}$ & $\begin{array}{c}1.1 \\
.7 \mathrm{~L} \\
\mathrm{~N} \\
1.5 \mathrm{~L} \\
\mathrm{~N}\end{array}$ & $\begin{array}{l}.090 \\
.080 \\
.080 \\
.020 \\
.060\end{array}$ & $\begin{array}{l}1.3 \mathrm{~L} \\
.19 \\
\mathrm{~N} \\
.21 \mathrm{~L} \\
\mathrm{~N}\end{array}$ & $\begin{array}{r}11 \\
3 \\
9 \\
6 \\
9\end{array}$ & $\begin{array}{l}\text { w191522 } \\
\text { s187043 } \\
\text { d170155 } \\
\text { w187041 } \\
\text { d170153 }\end{array}$ \\
\hline
\end{tabular}




\begin{tabular}{|c|c|c|c|c|c|c|c|c|c|c|c|}
\hline & $\begin{array}{c}\mathrm{Li} \\
(\mathrm{ppm})\end{array}$ & $\begin{array}{c}\mathrm{Lu} \\
(\mathrm{ppm})\end{array}$ & $\begin{array}{c}\mathrm{Mn} \\
(\mathrm{ppm})\end{array}$ & $\begin{array}{c}\text { Mo-S } \\
(\mathrm{ppm})\end{array}$ & $\begin{array}{c}\mathrm{Nb}-\mathrm{S} \\
(\mathrm{ppm})\end{array}$ & $\begin{array}{c}\text { Nd-S } \\
(\mathrm{ppm})\end{array}$ & $\begin{array}{c}\mathrm{Ni}-\mathrm{S} \\
(\mathrm{ppm})\end{array}$ & $\begin{array}{c}\mathrm{P} \\
(\mathrm{ppm})\end{array}$ & $\begin{array}{c}\mathrm{Pb} \\
(\mathrm{ppm})\end{array}$ & $\begin{array}{c}\mathrm{Pr}-\mathrm{S} \\
(\mathrm{ppm})\end{array}$ & \\
\hline 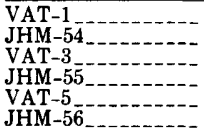 & $\begin{array}{l}26 \\
7.1 \\
27 \\
26 \\
7.0 \\
9.3\end{array}$ & $\begin{array}{l}0.3 \mathrm{~L} \\
\mathrm{~N} \\
.3 \mathrm{~L} \\
\mathrm{~N} \\
.1 \\
\mathrm{~N}\end{array}$ & $\begin{array}{l}21 \\
6.0 \\
16 \\
27 \\
6.5 \\
8.4\end{array}$ & $\begin{array}{l}1.5 \\
.60 \\
1.6 \\
1.3 \\
1.9 \\
2.1\end{array}$ & $\begin{array}{l}1.1 \\
.80 \\
3.1 \\
1.3 \\
.54 \\
\mathrm{~L}\end{array}$ & $\begin{array}{c}6.8 \mathrm{~L} \\
\mathrm{~L} \\
7.2 \mathrm{~L} \\
13 \\
6.5 \\
\mathrm{~L}\end{array}$ & $\begin{array}{c}10 \\
8.0 \\
15 \\
8.9 \\
6.5 \\
6.3\end{array}$ & $\begin{array}{l}110 \\
17 \mathrm{~L} \\
140 \\
210 \\
9 \\
17 \mathrm{~L}\end{array}$ & $\begin{array}{c}10 \\
2.2 \\
9.9 \\
4.9 \\
2.6 \\
2.7\end{array}$ & $\begin{array}{l}1.5 \\
\mathrm{~N} \\
2.3 \\
\mathrm{~N} \\
6.5 \mathrm{~L} \\
\mathrm{~N}\end{array}$ & $\begin{array}{l}\text { w187040 } \\
\text { d170150 } \\
w 187042 \\
\text { d170151 } \\
\text { w191521 } \\
\text { d170152 }\end{array}$ \\
\hline $\begin{array}{l}\text { VAT-6 } \\
\text { VAT-4 } \\
\text { JHM-59 } 90 \\
\text { VAT-2 } \\
\text { JHM-57 } \\
\text { JHM-58 }\end{array}$ & $\begin{array}{c}13 \\
5.4 \\
8.2 \\
8.2 \\
25 \\
11\end{array}$ & $\begin{array}{l}.1 \\
.1 \mathrm{~L} \\
\mathrm{~N} \\
.2 \mathrm{~L} \\
\mathrm{~N} \\
\mathrm{~N}\end{array}$ & $\begin{array}{c}12 \\
27 \\
33 \\
12 \\
27 \\
3.1\end{array}$ & $\begin{array}{l}1.7 \\
1.7 \\
2.4 \\
.96 \\
.89 \\
1.3\end{array}$ & $\begin{array}{l}1.8 \\
.45 \\
1.4 \\
1.1 \\
1.8 \\
.66\end{array}$ & $\begin{array}{l}9.0 \mathrm{~L} \\
2.2 \mathrm{~L} \\
7.1 \\
4.6 \mathrm{~L} \\
\mathrm{~N} \\
4.4\end{array}$ & $\begin{array}{l}8.0 \\
5.6 \\
7.1 \\
8.2 \\
8.9 \\
8.8\end{array}$ & $\begin{array}{c}4 \\
13 \mathrm{~L} \\
120 \\
44 \\
39 \mathrm{~L} \\
17 \mathrm{~L}\end{array}$ & $\begin{array}{l}6.3 \\
2.4 \\
4.7 \\
6.5 \\
5.8 \\
3.5\end{array}$ & $\begin{array}{r}13 \mathrm{~L} \\
.6 \\
\mathrm{~N} \\
1.0 \\
\mathrm{~N} \\
\mathrm{~N}\end{array}$ & $\begin{array}{l}\text { w191522 } \\
\text { w187043 } \\
\text { d170155 } \\
\text { w187041 } \\
\text { d170153 } \\
\text { d170154 }\end{array}$ \\
\hline & $\begin{array}{c}\mathrm{Rb} \\
(\mathrm{ppm})\end{array}$ & $\begin{array}{c}\mathrm{Sb} \\
(\mathrm{ppm})\end{array}$ & $\begin{array}{c}\mathrm{Sc} \\
(\mathrm{ppm})\end{array}$ & $\begin{array}{c}\mathrm{Se} \\
(\mathrm{ppm})\end{array}$ & $\begin{array}{c}\mathrm{Sm} \\
(\mathrm{ppm})\end{array}$ & $\begin{array}{c}\mathrm{Sn}-\mathrm{S} \\
(\mathrm{ppm})\end{array}$ & $\begin{array}{c}\mathrm{Sr}-\mathrm{S} \\
(\mathrm{ppm})\end{array}$ & $\begin{array}{c}\mathrm{Tb} \\
(\mathrm{ppm})\end{array}$ & $\begin{array}{c}\mathrm{Th} \\
(\mathrm{ppm})\end{array}$ & $\begin{array}{c}\mathrm{U} \\
(\mathrm{ppm})\end{array}$ & \\
\hline $\begin{array}{l}\text { VAT-1 } \\
\text { JHM-54 } \\
\text { VAT-3 }-1 .- \\
\text { JHM-55 } \\
\text { VAT-5 } \\
\text { JHM } 5 \overline{6}^{-}\end{array}$ & $\begin{array}{c}\mathrm{B} \\
\mathrm{B} \\
\mathrm{B} \\
\mathrm{B} \\
7 \\
\mathrm{~B}\end{array}$ & $\begin{array}{c}0.54 \\
.60 \\
1.4 \\
.40 \\
.69 \\
1.1\end{array}$ & $\begin{array}{l}2.9 \\
1.2 \\
4.1 \\
2.7 \\
1.3 \\
2.1\end{array}$ & $\begin{array}{r}1.3 \\
.8 \\
2.2 \\
.7 \\
.9 \\
1.4\end{array}$ & $\begin{array}{l}1.2 \\
\mathrm{~N} \\
2.0 \\
\mathrm{~N} \\
.90 \\
\mathrm{~N}\end{array}$ & $\begin{array}{l}1.5 \mathrm{~L} \\
\mathrm{~N} \\
1.6 \mathrm{~L} \\
\mathrm{~N} \\
.65 \mathrm{~L} \\
\mathrm{~N}\end{array}$ & $\begin{array}{l}180 \\
200 \\
260 \\
130 \\
130 \\
130\end{array}$ & $\begin{array}{r}1 \mathrm{~L} \\
\mathrm{~N} \\
\mathrm{~N} \\
2 \\
\mathrm{~N}\end{array}$ & $\begin{array}{c}4.0 \\
\text { B } \\
5.0 \\
3.2 \\
3.0 \mathrm{~L} \\
\text { B }\end{array}$ & $\begin{array}{l}1.3 \\
.54 \\
1.3 \\
.92 \\
1.0 \\
1.7\end{array}$ & $\begin{array}{l}\text { w187040 } \\
\text { d170150 } \\
\text { w187042 } \\
\text { d170151 } \\
\text { w191521 } \\
\text { d170152 }\end{array}$ \\
\hline 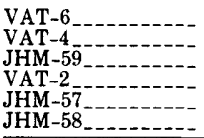 & $\begin{array}{l}15 \\
\mathrm{~B} \\
\mathrm{~B} \\
\mathrm{~B} \\
\mathrm{~B} \\
\mathrm{~B}\end{array}$ & $\begin{array}{l}.85 \\
1.0 \\
.60 \\
.30 \\
.50 \\
.60\end{array}$ & $\begin{array}{l}2.6 \\
.84 \\
2.4 \\
1.5 \\
4.5 \\
2.2\end{array}$ & $\begin{array}{l}2.5 \\
2.0 \\
2.7 \\
3.1 \\
1.1 \\
2.3\end{array}$ & $\begin{array}{l}1.9 \\
.42 \\
\mathrm{~N} \\
.80 \\
\mathrm{~N} \\
\mathrm{~N}\end{array}$ & $\begin{array}{l}1.3 \mathrm{~L} \\
.48 \mathrm{~L} \\
\mathrm{~N} \\
2.3 \\
\mathrm{~N} \\
.44\end{array}$ & $\begin{array}{r}150 \\
93 \\
140 \\
160 \\
180 \\
130\end{array}$ & $\begin{array}{l}.3 \\
.3 \mathrm{~L} \\
\mathrm{~N} \\
.7 \mathrm{~L} \\
\mathrm{~N} \\
\mathrm{~N}\end{array}$ & $\begin{array}{l}3.0 \mathrm{~L} \\
3.0 \mathrm{~L} \\
5.2 \\
4.0 \\
3.6 \\
3.3\end{array}$ & $\begin{array}{c}1.6 \\
.60 \\
.78 \\
.70 \\
1.3 \\
.62\end{array}$ & $\begin{array}{l}\text { w191522 } \\
\text { w187043 } \\
\text { d170155 } \\
\text { w187041 } \\
\text { d170153 } \\
\text { d170154 }\end{array}$ \\
\hline & $\begin{array}{c}\mathrm{V}-\mathrm{S} \\
(\mathrm{ppm})\end{array}$ & $\begin{array}{c}\mathrm{Y}-\mathrm{S} \\
(\mathrm{ppm})\end{array}$ & $\begin{array}{c}\mathrm{Yb} \\
(\mathrm{ppm})\end{array}$ & $\begin{array}{c}\mathrm{Zn} \\
(\mathrm{ppm})\end{array}$ & $\begin{array}{c}\mathrm{Zr}-\mathrm{S} \\
(\mathrm{ppm})\end{array}$ & & & & & & \\
\hline 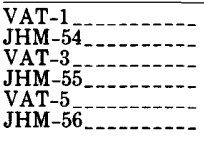 & $\begin{array}{l}18 \\
6.0 \\
31 \\
27 \\
8.6 \\
13\end{array}$ & $\begin{array}{l}7.3 \\
6.0 \\
9.5 \\
8.9 \\
5.2 \\
6.3\end{array}$ & $\begin{array}{r}0.7 \\
.4 \\
.9 \\
.9 \\
.5 \\
.4\end{array}$ & $\begin{array}{l}8.6 \\
4.5 \\
4.5 \\
3.5 \\
1.9 \\
9.1\end{array}$ & $\begin{array}{c}32 \\
12 \\
56 \\
18 \\
8.6 \\
4.2\end{array}$ & & & & & & $\begin{array}{l}\text { w187040 } \\
\text { d170150 } \\
\text { w187042 } \\
\text { d170151 } \\
\text { w191521 } \\
\text { d170152 }\end{array}$ \\
\hline $\begin{array}{l}\text { VAT-6 } \\
\text { VAT-4 } \\
\text { JHM } 59 . \\
\text { VAT-2 } \\
\text { JHM-57 } \\
\text { JHM-58 }\end{array}$ & $\begin{array}{l}17 \\
6.3 \\
14 \\
9.4 \\
13 \\
13\end{array}$ & $\begin{array}{l}6.5 \\
2.8 \\
9.4 \\
5.4 \\
8.9 \\
6.6\end{array}$ & $\begin{array}{l}.9 \\
.2 \\
.7 \\
.4 \\
.9 \\
.7\end{array}$ & $\begin{array}{l}6.2 \\
3.2 \\
7.1 \\
5.8 \\
3.0 \\
1.8\end{array}$ & $\begin{array}{l}17 \\
11 \\
14 \\
26 \\
27 \\
13\end{array}$ & & & & & & $\begin{array}{l}\text { w191522 } \\
\text { w187043 } \\
\text { d170155 } \\
\text { w187041 } \\
\text { d170153 } \\
\text { d170154 }\end{array}$ \\
\hline
\end{tabular}


TABLE 7.-Arithmetic mean, observed range, geometric mean, and geometric deviation of 38 elements in 12 coul samples from Virginia and West Virginia

[All values are in parts per million on a whole-coal basis]

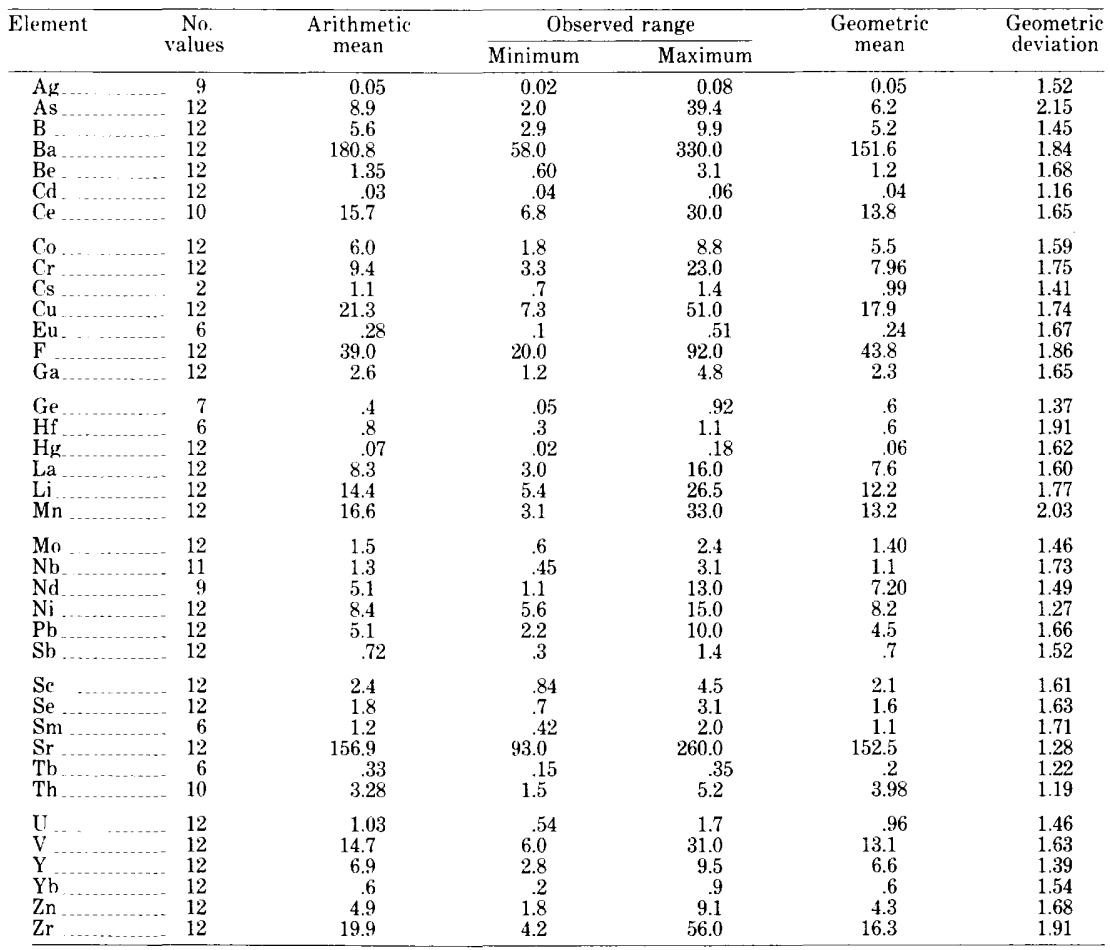

high moisture may be caused by weathered coal. Furthermore, comparisons of the analytical results show that as the percentage of ash increases in the 12 coal samples the densities increase also and the heat values decrease. The results indicate that the ash content of the coal(s) is directly proportional to its density and inversely proportional to its heat value.

\section{DENSITY (SPECIFIC GRAVITY)}

Coal resource and reserve calculations are based on an average density factor that experience has shown fits coal of a certain rank from a particular area. This density factor must be as representative as possible to make accurate and dependable coal-resource estimates. In southern West Virginia and southwestern Virginia, for example, bituminous coal resource and reserve calculations are based on a density of 13,235 metric tons per hectare-meter ( 1800 short tons per acre-foot) which is equal to a specific gravity ( $\mathrm{sp}$ gr) of 1.323 . Much valuable high-quality coal is mined on private properties in the Pocahontas district so it is important to the mining company and fee holder to be 
confident that the assessed tonnage royalties are based on a true and representative average density of the mined coal(s). With these considerations in mind, we obtained density determinations for the 12 coal samples from the Coal Analysis Section, U.S. Department of Energy.

Real specific-gravity values for the 12 coal samples (as received) from the study area are presented in table 1 . The mean density of the 12 coal samples from Virginia and West Virginia is $\mathrm{sp} \mathrm{gr}=1.35$; the range of values for the 12 coal samples is $\mathrm{sp}$ gr $=1.32$ to 1.43 and the mode or most frequent value is $\mathrm{sp} \mathrm{gr}=1.34$. The mean density, $\mathrm{sp} \mathrm{gr}=1.35$, is so close to the density factor used in the calculation of coal resources, $\mathrm{sp}$ gr $=1.323$, that the estimated volumes of coal in this area based upon these factors will be reasonably accurate. The percentage difference in the volumes of coal is just 1 percent. The data in table 1 show that as the ash content of the coal increases so does the density of the coal. This is because the minerals that constitute the ash in coal such as quartz, clay, feldspar, and accessory ore minerals all have densities greater than coal; when present in coal, these inorganic minerals increase the coal density. For purposes of comparison, pure vitrinite has a specific gravity of about 1.28 (van Krevelen, 1961). There does not appear to be a serial variation of the density of the coal samples shown in table 1 with their stratigraphic position or metamorphic rank. Rather, the density is directly proportional to the mass of the original organic and inorganic constituents of the coal(s). Within this range of rank these properties-moisture, ash, calorific value, and density-are all (with the possible exception of moisture) a function more of the original coal-bed composition than of coal rank.

\section{FREE-SWELLING INDEX NUMBER}

The free-swelling index number is an indicator of the capability of coal to form coke. An index number of 6 or higher indicates good coke-forming ability with the higher numbers suggesting greater coke-forming ability. All of the coal samples in table 1 form prominent coke buttons except sample VAT-6 (Pocahontas No. 4 coal) which has a free-swelling index of 1.5; that is noncoking-either because of the maceral composition of the coal or because the coal is weathered. As the channel sample for this coal was collected from a bench exposure faced-up by a bulldozer, there is a possibility that this coal sample is weathered or oxidized. The mode or most frequent free-swelling index number for 7 of the 12 coal samples is 9.0 . These data indicate that all five coal beds contain high-quality metallurgical-grade coking coal with the possible exception of local patches of Pocahontas No. 4 coal. The Horsepen coals form less prominent "coke buttons" than the Pocahontas coals probably because they contain somewhat higher percentages of ash. 


\section{ASH-FUSION TEMPERATURES}

Three ash-fusion temperatures are given in degrees Celsius for each of the 12 coal samples in table 1 . They are the initial deformation temperature, the softening temperature, and the fluid or melting temperature. As a general rule-of-thumb, for each sample, the softening and the fluid temperatures should be greater than the initial deformation temperature by approximately $30^{\circ}-40^{\circ} \mathrm{C}$ and $60^{\circ}-80^{\circ} \mathrm{C}$, respectively. All of the temperatures are indicative of each coal's ash-fusion properties and none of the results detract from the metallurgical quality of these coals.

\section{COAL PETROGRAPHY}

Petrographic compositions for a sample of the Upper Horsepen (JHM-54) and one of the Pocahontas No. 4 (JHM-59) coal beds are given in table 8 . These data were determined on a mineral-matter-free basis in volume percent and then corrected to a whole-coal basis using the Parr formula (American Society for Testing and Materials, 1974). The maceral composition provides for a comparison among samples and gives some indication as to the conditions prevailing in the original depositional environment.

The relatively low mineral-matter content and high inertinite and exinite content may indicate a depositional environment conducive to the oxidation of woody material (vitrinite) or high biochemical degradation (micrinite) and lack of formation of much mineral matter.

The mean maximum vitrinite reflectances were determined for the 12 coal-channel samples obtained from the study area. They are listed in stratigraphic order in table 9 along with their respective fixed-carbon values for comparison. Vitrinite reflectance is a measure of the degree of metamorphism and may or may not be directly correlative with rank which is affected by both metamorphism and maceral composition.

The reflectances appear to be correlative with the fixed-carbon content. The results in table 9 indicate that for the 12 coal samples in this study fixed-carbon and reflectance values increase in proportion to their stratigraphic depth or age. From the Upper Horsepen coal down to the Pocahontas No. 3 coal bed, a $244-\mathrm{m}(800-\mathrm{ft})$-thick sedimentary section, the fixed carbon and the reflectance increase from roughly 64 to 70 percent and from 1.22 to 1.42 percent, respectively. A regional petrographic study of 11 coal beds in southwestern Virginia and southern West Virginia gave similar results. Coal beds from the Lower Banner down to the Pocahontas No. 4 span about $487.8 \mathrm{~m}(1,600 \mathrm{ft})$ of stratigraphic section and the data are drawn from a much larger area than this investigation. The fixed-carbon and reflectance values of the coal samples increase from 64 to 72 percent and from 1.12 to 1.44 
TABLE 8. Petrographic analyses of two coal samples from McDowell County, West Virginia, and Tazewell County, Virginia

\begin{tabular}{|c|c|c|c|c|c|c|c|c|c|}
\hline \multirow{3}{*}{$\begin{array}{l}\text { Field } \\
\text { sample } \\
\text { number }\end{array}$} & \multirow{3}{*}{ Coal bed } & \multirow{3}{*}{ Vitrinite } & \multicolumn{7}{|c|}{ Maceral composition (mineral-matter-free, volume percent) } \\
\hline & & & \multicolumn{2}{|c|}{ Liptinite } & \multicolumn{5}{|c|}{ Inertinite } \\
\hline & & & Sporinite & Resinite & Fusinite & Semifusinite & Micrinite & Macrinite & Sclerotinite \\
\hline $\begin{array}{l}\text { JHM-54 } \\
\text { (D170150). }\end{array}$ & $\begin{array}{l}\text { Upper Horsepen, } \\
\text { Tazewell County, } \\
\text { Va. }\end{array}$ & 57 & 11 & $\mathrm{~T}^{2}$ & 3 & 8 & 16 & 5 & $\mathrm{~T}$ \\
\hline $\begin{array}{l}\text { JHM-59 } \\
(\mathrm{D} 170155) .\end{array}$ & $\begin{array}{l}\text { Pocahontas No. } 4 \text {, } \\
\text { McDowell County, } \\
\text { W. Va. }\end{array}$ & 83 & 1 & 1 & 1 & 6 & 5 & 3 & $\mathrm{~T}$ \\
\hline
\end{tabular}

\begin{tabular}{|c|c|c|c|c|c|c|c|c|c|}
\hline \multirow{3}{*}{$\begin{array}{l}\text { Field } \\
\text { sample } \\
\text { number }\end{array}$} & \multicolumn{9}{|c|}{ Whole coal petrographic analysis (volume percent) } \\
\hline & \multirow{2}{*}{$\begin{array}{l}\text { Mineral } \\
\text { matter: }\end{array}$} & \multirow{2}{*}{ Vitrinite } & \multicolumn{2}{|c|}{ Liptinite } & \multicolumn{5}{|c|}{ Inertinite } \\
\hline & & & Sporinite & Resinite & Fusinite & Semifusinite & Micrinite & Macrinite & Sclerotinite \\
\hline $\begin{array}{l}\text { JHM-54 } \\
\text { (D170150). }\end{array}$ & 2.2 & 56 & 11 & $\mathrm{~T}^{2}$ & 3 & 8 & 16 & 5 & $\mathrm{~T}$ \\
\hline $\begin{array}{l}\text { JHM-59 } \\
\text { (D170155). }\end{array}$ & 2.3 & 81 & 1 & 1 & 1 & 6 & 5 & 3 & $\mathbf{T}$ \\
\hline
\end{tabular}

Laboratory sample number

Trace $=$ Less than 1 percent

Calculated by Parr formula 
TABLE 9.-Reflectance and fixed carbon values for 12 coal samples from McDowell County, West Virginia, and Tazewell County, Virginia

[The analyses were performed using the ASTM standard method 2798. One hundred readings per sample were recorded, and the standard deviation of values was $\leq 0.05$ per sample]

\begin{tabular}{|c|c|c|c|}
\hline $\begin{array}{l}\text { Field sample } \\
\text { number }\end{array}$ & $\begin{array}{l}\text { Reflectance } \\
\text { (奋omax') }\end{array}$ & $\begin{array}{c}\text { Fixed carbon } \\
\text { (percent as received) }\end{array}$ & Coal bed \\
\hline VAT-1 & 1.22 & 62.3 & Upper Horsepen \\
\hline JHM-54 & 1.15 & 67.4 & Do. \\
\hline VAT-3 & 1.24 & 63.0 & Do. \\
\hline JHM-55_ & 1.28 & 64.9 & Do. \\
\hline VAT -5 & 1.24 & 66.1 & War Creek \\
\hline JHM-56. & 1.37 & 69.7 & Lower Horsepen \\
\hline VAT-6 & -1.29 & 59.9 & Pocahontas No. 4 \\
\hline VAT -4 & 1.28 & 66.3 & Do. \\
\hline JHM-59 & 1.40 & 72.3 & Do. \\
\hline VAT -2 & _- 1.40 & 68.3 & Pocahontas No. 3 \\
\hline JHM -57 & 1.42 & 69.7 & Do. \\
\hline JHM-58 & 1.42 & 72.1 & Do. \\
\hline
\end{tabular}

' $\bar{R}$ omax values $=$ percent mean maximum vitrinite reflectance.

percent, respectively, in direct proportion to their depth in the 487.8meter (1,600-ft) interval (U.S. Geological Survey, unpub. data, 1975).

Several general statements can be deduced from the data in tables 8 and 9: (1) the coal samples studied despite their high rank contain some exinite; (2) the Upper Horsepen coal-bed sample contains relatively small amounts of vitrinite and large amounts of inertinite; (3) vitrinite reflectance increases as the fixed-carbon content increases. The coal-sample analytical results obtained in this small $54 \mathrm{~km}^{2}$ study area are quite similar to the results observed in a regional petrographic study (U.S. Geological Survey, unpub. data, 1975).

\section{COAL GEOLOGY}

Commercial-scale coal mining began in the Pocahontas No. 3 coal bed near Pocahontas, Va., in 1892 when the New River branch of the Norfolk and Western Railroad was extended to Pocahontas (Harnsberger, 1919, p. 6). Early mine developments in the coal field were fully underway when M. R. Campbell of the U.S. Geological Survey completed work on the Pocahontas and Tazewell Folios $(1896,1897)$ wherein the areal geology of the Pocahontas region was described systematically and effectively. Since that time, and because of almost continuous operations, the coal companies have accumulated much additional coal information from mining operations and exploration activities. The study area is located in the mountainous Cumberland Plateau along the southern margin of the Pocahontas coal field adjacent to the Allegheny Front. It forms a stratigraphic link between three coal-bearing drainage basins where coal has been mined extensively by underground and surface methods. 


\section{FIELD OBSERVATIONS}

POCAHONTAS NO. 4 COAL BED

The Pocahontas No. 4 coal bed is mostly of metallurgical grade, but there are patches or scattered areas in the district where the quality and (or) thickness of the coal deteriorate. For example, a comparison of the analytical results in table 1 clearly shows that channel sample VAT-6 from the Pocahontas No. 4 coal bed is anomalous. In contrast to the other samples, VAT-6 contains greater amounts of moisture and ash, has the lowest "as received" heat value $(12,130 \mathrm{Btu} / \mathrm{lb}$ or 6,740 $\mathrm{kcal} / \mathrm{kg}$ ), has a very low free-swelling index (1.5), and has the highest density ( $\mathrm{sp} \mathrm{gr}=1.43$ ) of the 12 coal samples. When compared with the other coal beds in the area, the physical character of the Pocahontas No. 4 coal bed and its roof and floor rock reflect significant changes in the sedimentary environment. Cannel and bone (impure) coal are found sporadically in the area in the upper third of the Pocahontas No. 4 along with rash and clay partings. Although the thickness of the Pocahontas No. 4 is greater in the study area than it is further north, it also tends to be nonuniform and to have abrupt local facies changes that lead to splits and pinchouts. Quartz-pebble conglomerate was found in the base of the sandstone overlying the No. 4 coal at a nearby locality. These conditions suggest that locally the sedimentary basin was subject to a greater than usual influx of coarse clastics. Also, the basin contained swamp vegetation that yielded significant amounts of spores to the basin sediments. The spore-rich sediments were preserved locally, probably because of their depth of accumulation, and then were indurated to canneloid coal beds.

Mining experience in this area also indicates that the sulfur and ash content and coking properties of the Pocahontas No. 4 coal bed are locally erratic. A deep mine development near the study area along the south side of Jump Branch was discontinued because of high-sulfur values and the noncoking character of the coal. Washing eliminated the sulfur problem, according to Mr. Ralph McKee, Wyoming Mining Company (oral commun., 1975), but the economics of the operation did not make it attractive to mine the coal for steam generation. U.S. Steel Corporation in 1975 also tested a bulk sample of the Pocahontas No. 4 coal bed from this site, with the same results; thus, there was little interest in mining the coal.

\section{COLOR, TEXTURE, BANDING, AND HARDNESS}

The coal beds show no persistent and unusual colorations such as iron oxide staining because of the almost complete absence of mineral impurities, particularly pyrite. Cannel coal that is limonitic stained or rust colored and blocky structured occurs sporadically in the upper part only of the Pocahontas No. 4. Because several of the coal samples 
in this study were collected underground where the lighting was fair to poor, opportunities for detailed megascopic examinations were not favorable. All of the coal beds in this study except the canneloid parts are common banded with alternating bright vitrain bands and dull attrital coal. Generally, the coals are bright, and the banding in the Pocahontas Formation is variable from thin to medium thickness, whereas the overlying Horsepen coal beds in the New River Formation are generally medium to thick banded. The proportion of dull attrital coal is usually greater in the Horsepen coal beds, as their higher ash content and the petrographic analysis would suggest (see table 8). Dull attrital coal layers in the Horsepen coal beds are often very hard and have a granular texture and bright steely sheen. This type of coal, called "splint" variety, is also found locally in the base of the Pocahontas No. 4 coal bed. The hardness of the coal was not determined by laboratory tests but was noted during hand-chisel sampling, which was difficult. At the mine face this coal breaks with difficulty and has a conchoidal or uneven fracture.

\section{CLEAT (JOINTING)}

The natural vertical fracture system in bituminous coal beds is called cleat (McCulloch and others, 1974, p. 2). Probably the single most conspicuous feature of coals in the Pocahontas Formation is their fine-cleated or jointed character, which is a very favorable physical property. The amount of coal preparation such as crushing and screening is drastically reduced because the coal tends to break up into small lumps during mining. For this reason, those coal beds that are finely cleated seem to be the easiest to break. This is probably more a function of close-spaced jointing (cleating intensity) than it is of the coal's intrinsic hardness or resistance to abrasion. Coal composition, however, apparently does control the intensity of joint development.

A study of several coal beds in the Yorkshire coal field by Macrae and Lawson (1954) found that durain bands that were thicker than about $15 \mathrm{~cm}$ ( 6 in) had less than 5 fractures per foot of coal-bed thickness whereas the clean bright coal had 70 fractures per foot. The cleat frequency depends upon the rank and geologic history of the coal, but for a given rank in a coal field the frequency is determined by coal type. Although the Horsepen coal beds are cleated, the jointing is more widely spaced and not nearly as prominent as it is in the Pocahontas coal beds. These studies suggest that the fine-cleated character of the Pocahontas coals is primarily dependent not on depth of burial or intensity of deformation but rather on the original constituents of the coals. 
COAL BED THICKNESS (LATERAL VARIATION AND SPLITS)

The most productive coal beds in the study area have been Pocahontas No. 3 and No. 4. The Pocahontas No. 3 coal bed ranges in thickness from $1.5-2.3 \mathrm{~m}(5$ to $7.5 \mathrm{ft}$ ) throughout the study area and becomes even thicker toward the type section at Pocahontas, Va. In places the No. 3 has a carbonaceous shale parting as thick as $15.2 \mathrm{~cm}(0.5 \mathrm{ft})$ in the upper half of the coal bed. Mostly, however, it was a solid bed of coal which has now been mined out.

The thickness of the Pocahontas No. 4 coal bed in the study area, on the contrary, is much more variable-1.2-3.4 m (4-11 ft) thick at Monson, W. Va. The upper part of the No. 4 coal bed splits north and northeast of Monson and forms an upper bench that is commonly exposed on the top of a channel sandstone overlying the strip-mined No. 4 coal bed along the branches of the South Fork of the Tug River. The higher coal bed is called the No. 5 by the mine operators in the area.

The Lower Horsepen (company "No. 9") coal bed is stratigraphically the lowermost strip-mined coal along Big Stone Ridge and has a consistent thickness in the study area of $81.3-91.4 \mathrm{~cm}(32-36$ in). The War Creek coal bed is $55.8-66 \mathrm{~cm}$ (22-26 in) thick along the branches of Laurel Fork where it has been augered and strip mined. Another persistent coal bed, the Middle Horsepen, is about $15.2 \mathrm{~m}(50 \mathrm{ft})$ below the Upper Horsepen coal bed throughout the study area.

The Upper Horsepen coal bed, known as the "Smith seam" in the vicinity of Laurel Fork, is $2.1 \mathrm{~m}$ ( $7 \mathrm{ft}$ ) thick on the average in the study area but ranges from 0.9 to $3.4 \mathrm{~m}(3$ to $11 \mathrm{ft}$ ) in thickness. A noteworthy feature of the Horsepen coal zone is the splitting of the Upper Horsepen coal bed into two benches along the highest strip-mined level on Big Stone Ridge. Where the two coal benches merge, the thickest coal bed in the area is found. At one location, a tongue 7.6-10.7 m (25-35 feet) thick of massive sandstone separates the two coal benches. The

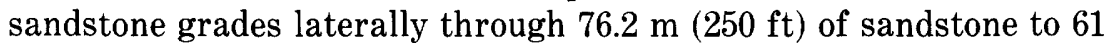
$\mathrm{cm}(2 \mathrm{ft})$ of carbonaceous sandstone and shale. Nearby, the two coal benches merge into one coal bed, so this represents a rapid facies change. Not enough data are available to enable us to characterize this unit as a bar, a beach, or a delta-plain sand member. However, the wedge of sandstone between the benches of coal is interpreted to be a contemporaneous sheet of sand that was deposited along the margins of a deepening or persistent coal swamp. Erratic rolls of the seat rock are common and result in sudden changes in coal elevation and thickness. These features are probably due to changes in thickness and compaction rates of the sediments. Sand would be relatively incompressible, whereas water-saturated peat and carbonaceous shales would be compressed considerably by the overlying sediment load. The 
distribution of the Upper Horsepen coal bed suggests "near-shore" lenselike deposits of thick coal whose axes trend southeast.

ROOF- ANI) FLOOR-ROCK CHARACIERISTICS

The roof and floor rock of coal beds in the study area are siltstone, sandstone, shale, mudstone, and combinations of these lithologies. Prominent spheroidal features as much as several meters in diameter were noted in the highwall strata of strip mines during geologic mapping of the Anawalt quadrangle in McDowell County, W. Va. They have a flattened ellipsoidal to round shape and occur in strata of the Pocahontas and New River Formations of Pennsylvanian age. The spheroidal features are well developed in sandstone, shale, and siltstone, and appear to be better formed in siltstone or sandy shale. These competent and incompetent interbedded rocks are much jointed and react differently to deformational stress; one result is that they show a conspicuous development of spheroidal jointing. These spheroidal features also seem to be better developed toward the axial plane of the Dry Fork anticline. Weathering of the rock is facilitated by closespaced jointing, but it is not sufficient to ascribe these oblate spheroids to weathering processes alone. Spheroidal weathering of sandstone has been described by Heald and others (1979) in the Kanawha Formation (Pennsylvanian) of Nicholas County, W. Va. The formation of concentric sandstone shells in sandstone containing micaceous and argillaceous material was apparently promoted by the expansion of layered silicates (phyllosilicates). Where the sandstone is composed of clean quartz, however, the spheroidal weathering is completely absent. The spheroidal features described here result from deformational forces exerted on rocks of differing strength. The jointed character of the rock permits physical and chemical alterations which probably assist in the development of these features. The spheroids do seem to be more fully formed in shaly strata which might suggest that expandable clay minerals are a factor in their formation. Probably both processes-jointing and then weathering along planes of weakness in the rock-contributed to the formation of the spheroidal features.

The jointed nature of the roof rock has proved to be a major problem in underground mining of the Pocahontas No. 4 coal bed at U.S. Steel Corporation's Road Fork mine (located at VAT-4 on pl. 1). Extra-long roof bolts and steel screen matting were used under wide areas of the roof to hold the fractured rock in place. The company attempted a short-wall mining method in this mine to compensate for the tendency of the roof to collapse. The technique did not prove successful, however, because of the changeable thickness of the Pocahontas No. 4 and because of rolls in the floor elevation of the coal. Experienced miners are of the opinion that when a coal bed such as the Pocahontas No. 4 has 
been strip mined prior to deep mining, the coal is particularly difficult to mine underground toward the surface because of bad roof conditions. From the experience in the Road Fork mine, this would seem to be a logical result of disturbing highly fractured rock.

\section{COAL-RANK VARIATIONS BY BED}

Three conventional methods of studying the rank of coal are by the analysis of (1) the Parr corrected fixed-carbon values, (2) the vitrinite reflectance values, and (3) the carbon-hydrogen atomic ratios. For a single coal bed, some dispersion or spread of these values is common. In the case of the fixed-carbon values, this is a result of differences in the maceral composition of the coal. The spatial variation of these three sets of values for the 12 coal samples from Virginia and West Virginia is shown by bed on plate 3. For three of the coal beds, each set of values constitutes a polygon of values whose resultant vector of advancing metamorphic grade bears about west-southwest. The other two coal beds, War Creek and Lower Horsepen, have only one sample each; therefore no bed analysis can properly be made for those values. They may be considered, however, as part of the same coal zone and be evaluated with that reservation in mind.

The vector diagrams on plate 3 represent a graphical resolution of coal-rank values for single coal beds from a small area of a regional fold. If all of the folding stresses on a single coal bed from the same small area along the limb of the regional fold are resolved, the resultant vector will be directed west-southwest also, to where the stresses intensify. Apparently this part of the fold was buried more deeply, but this factor is not as critical to the further advancement of the coal rank as is the increased pressure and temperature regime of close-folded rock.

\section{POCAHONTAS NO. 3 COAL BED}

The near isosceles triangle formed by the coal samples VAT-2, JHM-58, and JHM-57 is plotted on plate 3 with the three sets of values that are indices of metamorphic grade. If each of the three sets of values is considered separately, the resultant vector of the values in each polygon of values is increasing metamorphic grade towards the west-southwest or roughly $255^{\circ}$. This azimuth is nearly parallel to the axis of the Pocahontas syncline, so it is reasonable to associate the increase in rank with increased deformational stress to the southwest. Because the Pocahontas syncline plunges gently west-southwest, the result is most likely due to the increasing stress toward the fold-axis convergence, and, to a lesser extent, to the apparent increasing depth of burial in that direction. For the other coal beds, the data are not as reliable or well spaced, but the values suggest the same pattern of results. 
The irregular polygon of values for coal samples VAT-6, VAT-4, and JHM-59 almost forms a straight-line progression. However, because sample VAT-6 is probably oxidized, it does not fit the progressive increase of these values toward the southwest. If coal sample VAT-6 is not considered, the resultant vector(s) of the two sets of values for samples VAT-4 and JHM-59 have a bearing of about $255^{\circ}$, similar to the Pocahontas No. 3 coal-bed samples.

\section{WAR CREEK-LOWER HORSEPEN COAL ZONE}

No hard argument can be made for the War Creek (VAT-5) and Lower Horsepen (JHM-56) coal samples because they are not coeval. They are close in stratigraphic position, however (see pl. 2), so the two sets of values can be evaluated in terms of a coal zone. The resultant vector(s) of these values increases to the southwest like the Pocahontas No. 3 and No. 4 results.

\section{UPPER HORSEPEN COAL BED}

The four samples collected from the Upper Horsepen coal bed are plotted as circles on plate 3 and form a polygon of values. The sets of values for three of the coal samples increase from northeast to southwest along the plunge of the structure, and they also increase southeastward toward the beds that are upturned along the structural front. The single coal sample that does not fit this pattern, JHM-54, is anomalous and therefore was excluded from the stress diagram or polygon (see pl. 3). Even though the reflectance and fixed-carbon values of sample JHM-54 are low and reverse the increasing southwestward and increasing southeastward trend of values, we believe they are accurate. The only explanation that we can offer for the anomalous values is that there might be a small undetected structure (fracture) that has effectively released the built-up stress in the Upper Horsepen coal bed at this location. The rapid increase in reflectance and fixed-carbon values from JHM-54 to JHM-55 (1.15-1.28 and 71.16-74.20, respectively) are attributed to the abrupt folding of the coal bed along the structural front (see pl. 3). On the geologic map this is denoted by the southward termination of the Upper Horsepen coal bed along the stripped benches on either side of Horsepen Creek and Dalton Branch and at the head of Laurel Fork. The Parr-corrected fixed-carbon value for sample JHM-54 was rechecked and found to be correct. The three sets of values for three samples of the Upper Horsepen coal bed all have a resultant vector, $R$, that is alined west-southwest or about $250^{\circ}$ azimuth (see pl. 3). This is quite similar to the results for the Pocahontas No. 3 coal bed. 
Coal rank is directly proportional to the deformation of the coal beds in the Virginia-West Virginia study area. A thorough review and discussion of this subject was presented by Gordon H. Wood, Jr. (1969, p. 134-137) for field investigations in part of the Southern Anthracite field, Pennsylvania. Contours of equal fixed carbon (isocarb contours) closely parallel the structure contours in the area studied. Where folding stresses intensified, such as in the nose of tight synclinal folds, the fixed-carbon values for that particular coal bed increased also. Wood concluded that the rank of the coals in that part of the Southern Anthracite field is directly proportional to the deformational stresses put upon them.

Interpretation of the data presented here suggests that three coal beds, the Pocahontas No. 3 and No. 4 and the Upper Horsepen, increase in metamorphic grade and coal rank in a west-southwest direction through the study area. The vectors of advancing metamorphic grade and coal rank generally coincide with the axis of the Pocahontas syncline which plunges gently in the same direction. A component of the Upper Horsepen vector increase is directed toward the southeast where the beds are folded along the structural front. The notable increased reflectance and fixed-carbon values from sample JHM-54 to sample JHM-55 are a result of the increasing fold pressures toward the upturned beds. In this study area, as well as in the Southern Anthracite field, the isocarb contours parallel the main structure contours; therefore, the coal indices or values must have resulted at least in part from the tectonics that produced the primary structure of the area. There is a definite increase in coal rank with depth of burial of these coal beds, and there is also strong evidence for an increase in metamorphic grade and coal rank within individual coal beds related to the pressures of deformation.

The data presented suggest that the depth of burial and the increasing pressures of folding were the principal factors in determining the metamorphic grade and rank of the coal beds in this study area. An intuitive guess about the limits of each process is that load metamorphism resulting from the depth of burial would advance coal rank from the peat stage of coalification to the lower boundary of the mediumvolatile bituminous-coal-rank class. Then, to further advance the coal through the medium-volatile bituminous-coal-rank class, the added pressures of folding are necessary.

\section{ENVIRONMENTS OF COAL DEPOSITION}

An ancient shoreline migrated back and forth across the study area many times during the Early Pennsylvanian while the Pocahontas and New River Formations were being deposited. Just landward of these strandlines were located large swamps in which great amounts of 
peat-forming vegetation were being periodically deposited. The sea was in regression to the northwest during most of the depositional history of the Pocahontas and New River Formations and was receiving sediments from sources southeast of the area of investigations. Most of the thicker coal beds were deposited in the southeastern parts of the Pocahontas coal field along the Allegheny Front. According to a definitive study of the Pocahontas Formation by Englund (1974, pp. 31-45), a clastic wedge of sandstone, siltstone, shale, coal, and underclay is transitional between underlying marine strata of Mississippian age and overlying continental beds of Pennsylvanian age. The Pocahontas Formation attains a maximum thickness of $229 \mathrm{~m}(750 \mathrm{ft})$ at the southeastern edge of the coal field near Tazewell, Va. Sandstone which constitutes about 70 percent of the formation forms lenticular bodies that have distinct distribution patterns. These sediment distribution patterns show that the Pocahontas Formation was deposited mainly in deltaic complexes built out from the southeast during marine regression to the northwest. Brief periods of transgression and stable shoreline conditions are recorded by tongues of marine strata and barrier bars (Englund, 1974, p. 31).

If we judge from the coal bed thicknesses, the study area is near a locus of thick deposits of coal. The thicker coal beds are the Pocahontas No. 3 at Pocahontas, Va., the Pocahontas No. 4 at Monson, W. Va., and the Upper Horsepen coal bed along Big Stone Ridge in Tazewell County, Va. Coarse-grained clastic sediments constitute a greater part of the section in the study area towards the southeast. To illustrate, a lense of quartz-pebble conglomerate in sandstone overlies the Pocahontas No. 4 coal near the Road Fork mine. Geologic mapping reveals that fine-grained clastic sediments were deposited in greater quantities to the north and northwest in a deeper water offshore environment. It also reveals that splitting of coal beds is more common to the northwest of the deepest part of the basin. A short distance north of the study area, thin-bedded siltstone that has flaser bedding and fine cross laminations indicates shallow-water deposition in the lower part of the Pocahontas Formation. From these observations it is concluded that in Early Pennsylvanian time an old shoreline was situated northwest of the area of investigations.

The lithologies and stratigraphic relationships of the coal-bearing rocks of the study area suggest a coastal plain-deltaic environment. Ancient stream channels filled by sand are of minor importance in the Pocahontas and New River Formations of the area and were not a primary factor in the erosion of the coal beds or in the diminution of their thicknesses. The changes in thickness and variation of sediment facies associated with the Pocahontas No. 4 coal, however, are characteristics which seem more typical of a deltaic setting. The Upper 
Horsepen coal might represent a nearshore trough or lenselike deposits of coal. Such nearshore conditions would have permitted oxidation of the woody material accumulated in the swamps; this possibility is supported by coal petrographic analysis. Thus, the Horsepen coal swamps might have been situated on a plain as localized back-bay deposits that resulted in variable thicknesses of coalified material.

\section{CONCLUSIONS}

Physical and chemical analyses of 12 coal-channel samples from McDowell County, W. Va., and Tazewell County, Va., indicate that 11 samples are of metallurgical quality. The 11 samples consist of medium-volatile bituminous coal that is low in sulfur and ash and of good coking quality. Major-, minor-, and trace-element analyses performed on these coal samples for roughly 70 inorganic elements and oxides in whole coal and coal ash indicate no anomalous quantities or deleterious amounts of chemical elements. The 12 coal samples have densities directly proportional to their ash content and heat of combustion or Btu values that are inversely proportional to their ash content. There is no serial variation of the coal densities with their stratigraphic position or rank. Some properties of coal such as density, ash content, moisture, and Btu value are a function more of the original composition of a coal than of its stratigraphic position or metamorphic rank.

Another interesting aspect of the coal analyses is the increase in coal rank and metamorphic grade resulting from the higher pressure and temperature gradients associated with two factors: (a) depth of burial and geologic time and (b) structural deformation. The coal samples from the area of investigations in Virginia and West Virginia increase in rank by a reduction of volatile matter from 29 to 22 percent through about $244 \mathrm{~m}(800 \mathrm{ft})$ of stratigraphic distance or depth in this case. This loss of volatile matter cannot be attributed entirely either to depth of burial or to folding. Where deformation is clearly a factor in the bed-by-bed variations of fixed carbon and reflectance values, the changes are small compared with the same variations between the coal beds (see pl. 3). For example, four coal samples in stratigraphic order, VAT-3, JHM-56, JHM-59, and JHM-57 are located within $1.6 \mathrm{~km}$ (1 mi) of each other east of Low Gap Branch near the four-quadrangle join area. Significant differences of fixed carbon and reflectance occur between the younger and older coal beds; these differences cannot totally be a result of deformation because the coal samples are so closely spaced that the effects of folding are minimized. Because of the narrow range of values, the within-bed variations of coal-rank values due to folding cannot be equated with the greater between-bed variations of rank indices that are a result of age and depth of burial. 
Vitrinite reflectance is another reliable measure of the degree of metamorphism of a coal bed. The analysis of reflectance and fixedcarbon values for each of three coal beds shows that the rank increases in the direction of plunge of the Pocahontas syncline and also increases toward the upturned beds along the structural front. Most likely the coal rank increases are a result of both original depth of burial and the subsequent folding of the coal beds. Because we are dealing in this study area with coals whose ranks span the mediumvolatile bituminous-coal-rank class, we believe that depth of burial is cause enough to advance the rank of the coal beds up to the mediumvolatile bituminous-coal-rank class. Then further advancement of the coal rank through the medium-volatile bituminous-coal-rank class will require the increased pressure and temperature that result from folding.

The area of study in Virginia and West Virginia is located along the southeastern edge of the Appalachian coal field where the coalbearing Pocahontas Formation attains its maximum thickness of about $229 \mathrm{~m}(750 \mathrm{ft})$. The rocks are transitional between underlying marine strata of Mississippian age and overlying continental beds of Pennsylvanian age. Periodically, coal beds were deposited in large swamps and back-bay lagoons. The sea was regressing for the most part at this time with mostly arenaceous sediments being supplied from sources southeast of the study area. Stratigraphy and lithologic studies suggest that the coals were deposited in a coastal plain-deltaic environment. Generally the coals are thicker toward the southeast and coal-bed splits extend northwestward. Local abrupt facies changes that suggest less uniform coal thickness and composition were observed in rock associated with the Pocahontas No. 4 and Upper Horsepen coals.

The information presented in this report results from continuing efforts by the U.S. Department of Energy and the U.S. Geological Survey to make available modern, accurate, in-depth coal-quality data applicable to coal use in this country today. Current plans by industry and government suggest that U.S. coal production will be greatly expanded in the next two decades to help meet our energy production needs and thus reduce imports of costly petroleum. Most of the coal produced will be used in coal-fired powerplants, but conversion processes will also require large tonnages of coal feedstocks for synthetic fuels production. Coal-quality data will be needed by combustion and conversion engineers to design these plants for efficient operations and so that adverse impacts on the environment can be avoided. The information is available for planning purposes and technological study in the National Coal Resource Data System (NCRDS), U.S. Geological Survey, Reston, Va. 22092. 


\section{REFERENCES CITED}

American Society for Testing and Materials, 1974, Standard specifications for classification of coals by rank, ASTM designation: D388-66, (reapproved 1972), in 1974, Annual book of ASTM standards, pt. 26; Philadelphia, Pa., p. 54-58.

Campbell, M. R., 1896, Pocahontas [Quadrangle], Virginia-West Virginia, folio 26 of Geologic atlas of the United States: U.S. Geological Survey.

1897. Tazewell [Quadrangle], Virginia-West Virginia, folio 44 of Geologic atlas of the United States: U.S. Geological Survey.

Englund, K. J., 1968, Geologic map of the Bramwell quadrangle, West Virginia-Virginia: U.S. Geological Survey Geologic Quadrangle Map GQ-745, scale 1:24,000.

1974, Sandstone distribution patterns in the Pocahontas Formation of southwest Virginia and southern West Virginia: Geological Society of America Special Paper 148, p. $31-45$.

Harnsberger, T. K., 1919, The geology and coal resources of the coal-bearing portion of Tazewell County, Virginia: Virginia Geological Survey Bulletin 19, 195 p.

Heald, M. T., Hollingsworth, T. J., and Smith, R. M., 1979, Alteration of sandstone as revealed by spheroidal weathering: Journal of Sedimentary Petrology, v. 49, no. 3, p. 901-909.

Hennen, R. V., and Gawthrop, R. M., 1915, Wyoming and McDowell Counties: West Virginia Geological Survey [County Report], 783 p.

Hilt, Carl, 1873, Die Bezsiehungen zwischen der Zusammensetzung und den technischen Eigenschaften der Steinkohle: Verein Deutscher Ingenieure Zeitschrift, v. 17, no. 2, p. 194-202.

Krevelen, D. W. van, 1961, Coal; typology-chemistry-physics-constitution: AmsterdamLondon-New York, Princeton, Elsevier, 514 p.

Lee, W. H. K., and Clark, S. P., Jr., 1966, Heat flow and volcanic temperatures in Handbook of physical constants: Geological Society of America Memoir 97, p. 483-511.

Macrae, J. C., and Lawson, W., 1954, The incidence of cleat fracture in some Yorkshire coal seams: Leeds Geological Association Transactions, v. 6, pt. 5, p. 227-242.

McCulloch, C. M., Deul, Maurice, and Jeran, P. W., 1974, Cleat in bituminous coal beds: U.S. Bureau of Mines Report of Investigations 7910, 25 p., 13 figures.

Schopf, J. M., 1960, Field description and sampling of coal beds: U.S. Geological Survey Bulletin 1111-B, p. 25-70, 22 plates, 1 figure.

Stadnichenko, Taisia, 1934, Progressive regional metamorphism of the Lower Kittanning coal bed of western Pennsylvania: Economic Geology, v. 29, no.6, p. 511-543, 10 figures.

Swanson, V. E., and Huffman, Claude, Jr., 1976, Guidelines for sample collecting and analytical methods used in the U.S. Geological Survey for determining chemical composition of coal: U.S. Geological Survey Circular 735, 11 p.

Swanson, V. E., Medlin, J. H., Hatch, J. R., Coleman, S. L., Wood, G. H., Jr., Woodruff, S.D., and Hildebrand, R.T., 1976, Collection, chemical analysis, and evaluation of coal samples in 1975: U.S. Geological Survey Open-File Report 76-468, 503 p., 9 figures.

Teichmuller, Marlies, and Teichmuller, Rolf, 1966, Geological causes of coalification in American Conference on Coal Science: Washington, D.C., American Chemical Society, p. 133-155.

Trumbull, J. V. A., 1960, Coal fields of the United States, Sheet 1: U.S. Geological Survey, scale 1:5,000,000.

U.S. Bureau of Mines, 1967, Methods of analyzing and testing coal and coke: U.S. Bureau of Mines Bulletin 638, 82 p., 50 figures.

Welch, I. A., 1896, The Pocahontas-Flat Top Coal Fields: Daily Telegraph, Bluefield, West Virginia, November 1, 1896.

Wood, G. H., Jr., Trexler, J. P., and Kehn, T. M., 1969, Geology of the west-central part of the Southern Anthracite field and adjoining areas, Pennsylvania: U.S. Geological Survey Professional Paper 602, 150 p., 4 pls., 42 figs. 
